\title{
Engineering Evaluation/Cost Analysis for Decontamination at the St. Louis Downtown Site, St. Louis, Missouri
}

May 1991

prepared by

M.H. Picel, H.M. Hartmann, and M.R. Nimmagadda

Environmental Assessment and Information Sciences Division, Argonne National Laboratory

and M.J. Williams

Bechtel National, Inc., Oak Ridge, Tennessee

prepared for

U.S. Department of Energy, Oak Ridge Operations Office, Formerly Utilized Sites Remedial Action Program, under Contract W-31-109-Eng-38

\section{MASTER}




\section{CONTENTS}

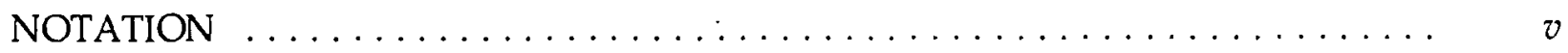

1 OVERVIEW AND SUMMARY $\ldots \ldots \ldots \ldots \ldots \ldots \ldots \ldots \ldots \ldots \ldots$

2 SITE CHARACTERIZATION $\ldots \ldots \ldots \ldots \ldots \ldots \ldots \ldots \ldots \ldots \ldots$

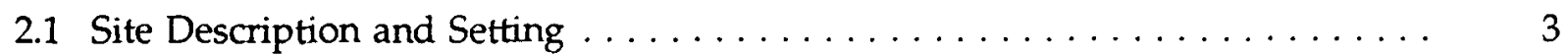

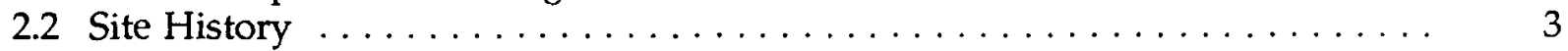

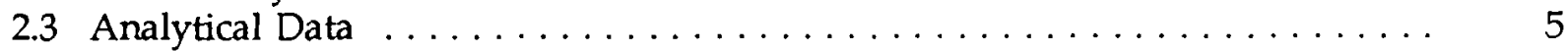

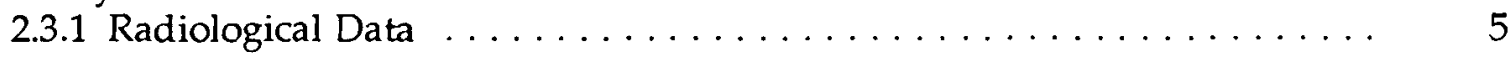

2.3.2 Chemical Data . . . . . . . . . . . . . . . . . . . . . . 7

2.4 Site Conditions that Justify a Removal Action . . . . . . . . . . . . . 9

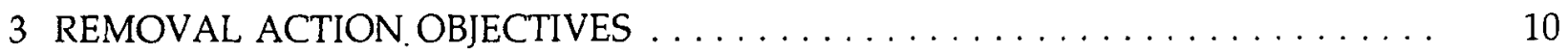

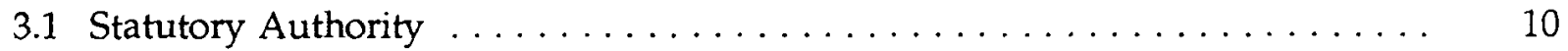

3.2 Compliance with Applicable or Relevant and Appropriate Requirements . . . 11

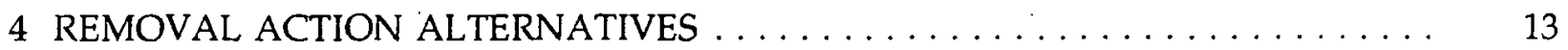

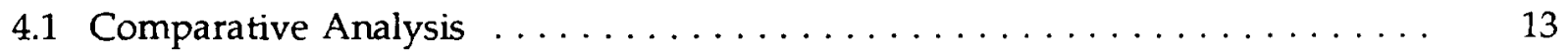

4.2 Identification of the Preferred Alternative $\ldots \ldots \ldots \ldots \ldots \ldots \ldots \ldots \ldots \ldots$

,5 DESCRIPTION OF THE PREFERRED ALTERNATIVE $\ldots \ldots \ldots \ldots \ldots \ldots$

6 HEALTH AND ENVIRONMENTAL IMPACTS OF THE

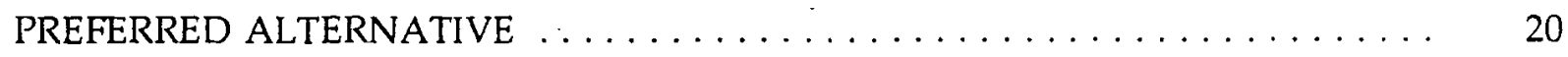

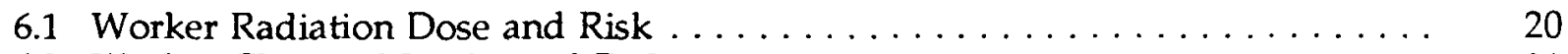

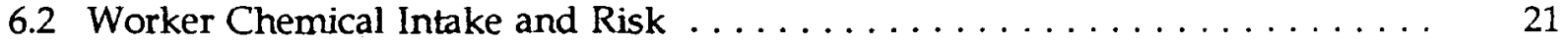

6.3 Public Health Impacts . . . . . . . . . . . . . . . . . . . . 22

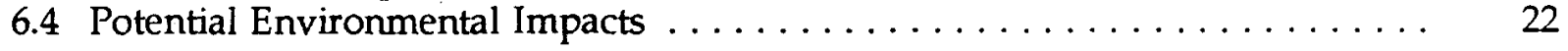

REFERENCES ............................. 24

$\begin{array}{ll}\text { APPENDIX A: } & \begin{array}{l}\text { Regulatory Requirements Potentially Applicable or Relevant } \\ \text { and Appropriate to the Proposed Action } \ldots \ldots \ldots \ldots \ldots \ldots \ldots\end{array}\end{array}$

APPENDIX B: English/Metric - Metric/English Equivalents . . . . . . . . . 69 


\section{FIGURES}

1 Location of FUSRAP Sites in the St. Louis, Missouri, Area . . . . . . . . . 1

2 St. Louis Downtown Site $\ldots \ldots \ldots \ldots \ldots \ldots \ldots \ldots \ldots \ldots \ldots \ldots \ldots \ldots \ldots$

3 Potential Interim Storage Plan for the First Floor of Building $116 \ldots \ldots \ldots \ldots$

\section{TABLES}

1 Summary of Radiological Characteristics Outside of Buildings

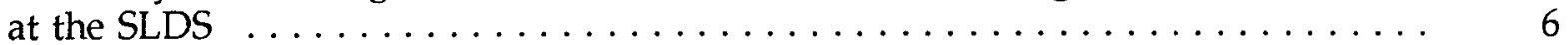

2 Summary of Radiological Characteristics Inside of Buildings

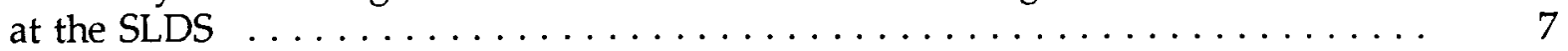

3 Summary of Metal and PAH Concentrations in Soil at the SLDS . . . . . . 8

4 Major Mitigative Measures for the Proposed Action . . . . . . . . . . . . . . . 19

5 Estimated Radiation Exposures and Health Risks to a Hypothetical Decontamination Worker ........................ 21

A.1 Potential Location-Specific Requirements $\ldots \ldots \ldots \ldots \ldots \ldots \ldots \ldots \ldots$

A.2 Potential Contaminant-Specific Requirements . . . . . . . . . . . . . . 37

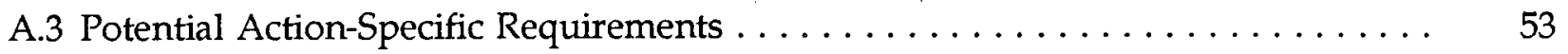




\section{NOTATION}

The following is a list of acronyms, initialisms, and abbreviations (including units of measure) used in this document.

\section{Acronyms, Initialisms, and Abbreviations}

\begin{tabular}{|c|c|}
\hline $\mathrm{AEC}$ & Atomic Energy Commission \\
\hline ALARA & as low as reasonably achievable \\
\hline ARAR & applicable or relevant and appropriate requirement \\
\hline CERCLA & $\begin{array}{l}\text { Comprehensive Environmental Response, Compensation, and } \\
\text { Liability Act }\end{array}$ \\
\hline CFR & Code of Federal Regulations \\
\hline $\mathrm{DOE}$ & U.S. Department of Energy \\
\hline $\mathrm{EE} / \mathrm{CA}$ & engineering evaluation/cost analysis \\
\hline EIS & environmental impact statement \\
\hline $\mathrm{EP}$ & extraction procedure \\
\hline EPA & U.S. Environmental Protection Agency \\
\hline FS & feasibility study \\
\hline FUSRAP & Formerly Utilized Sites Remedial Action Program \\
\hline HISS & Hazelwood Interim Storage Site \\
\hline MED & Manhattan Engineer District \\
\hline NEPA & National Environmental Policy Act \\
\hline NRC & U.S. Nuclear Regulatory Commission \\
\hline $\mathrm{PAH}$ & polycyclic aromatic hydrocarbon \\
\hline RI & remedial investigation \\
\hline RCRA & Resource Conservation and Recovery Act \\
\hline ROD & record of decision \\
\hline SLAPS & St. Louis Airport Site \\
\hline SLDS & St. Louis Downtown Site \\
\hline TBC & to-be-considered (requirements) \\
\hline
\end{tabular}

\section{Units of Measure}

$\begin{array}{ll}\mathrm{cm} & \text { centimeter(s) } \\ \mathrm{cm}^{2} & \text { square centimeter(s) } \\ \mathrm{dpm} & \text { disintegration(s) per minute } \\ \mathrm{ft} & \text { foot (feet) } \\ \mathrm{g} & \text { gram(s) } \\ \mathrm{h} & \text { hour(s) } \\ \mathrm{ha} & \text { hectare(s) } \\ \mathrm{in} . & \text { inch(es) } \\ \mathrm{kg} & \text { kilogram(s) } \\ \mathrm{km} & \text { kilometer(s) } \\ \mathrm{L} & \text { liter(s) } \\ \mu \mathrm{R} & \text { microRoentgen(s) }\end{array}$




$\begin{array}{ll}\mathrm{m} & \text { meter(s) } \\ \mathrm{m}^{2} & \text { square meter(s) } \\ \mathrm{m}^{3} & \text { cubic meter(s) } \\ \mathrm{mg} & \text { milligram (s) } \\ \mathrm{mi} & \text { mile(s) } \\ \mathrm{mrem} & \text { millirem(s) } \\ \mathrm{pCi} & \text { picocurie(s) } \\ \mathrm{WL} & \text { working level } \\ \text { WLM } & \text { working level month } \\ \mathrm{yd}^{3} & \text { cubic yard(s) } \\ \mathrm{yr} & \text { year(s) }\end{array}$




\section{DISCLAIMER}

This report was prepared as an account of work sponsored by an agency of the United States Government. Neither the United States Government nor any agency Thereof, nor any of their employees, makes any warranty, express or implied, or assumes any legal liability or responsibility for the accuracy, completeness, or usefulness of any information, apparatus, product, or process disclosed, or represents that its use would not infringe privately owned rights. Reference herein to any specific commercial product, process, or service by trade name, trademark, manufacturer, or otherwise does not necessarily constitute or imply its endorsement, recommendation, or favoring by the United States Government or any agency thereof. The views and opinions of authors expressed herein do not necessarily state or reflect those of the United States Government or any agency thereof. 


\section{DISCLAIMER}

Portions of this document may be illegible in electronic image products. Images are produced from the best available original document. 


\section{OVERVIEW AND SUMMARY}

The U.S. Department of Energy (DOE) is implementing a cleanup program for three groups of properties in the St. Louis, Missouri, area: (1) the St. Louis Downtown Site (SLDS), (2) the St. Louis Airport Site (SLAPS) and vicinity properties, and (3) the Latty Avenue Properties, including the Hazelwood Interim Storage Site (HISS). The general location of these properties is shown in Figure 1; the properties are referred to collectively as the St. Louis Site. None of the properties are owned by DOE, but each property contains radioactive residues from federal uranium processing activities conducted at the SLDS during and after World War II.

The activities addressed in this environmental evaluation/cost analysis (EE/CA) report are being proposed as interim components of a comprehensive cleanup strategy for the St. Louis Site. As part of the Department's Formerly Utilized Sites Remedial Action Program (FUSRAP), DOE is proposing to conduct limited decontamination in support of proprietor-initiated activities at the SLDS, commonly referred to as the Mallinckrodt Chemical Works. The primary

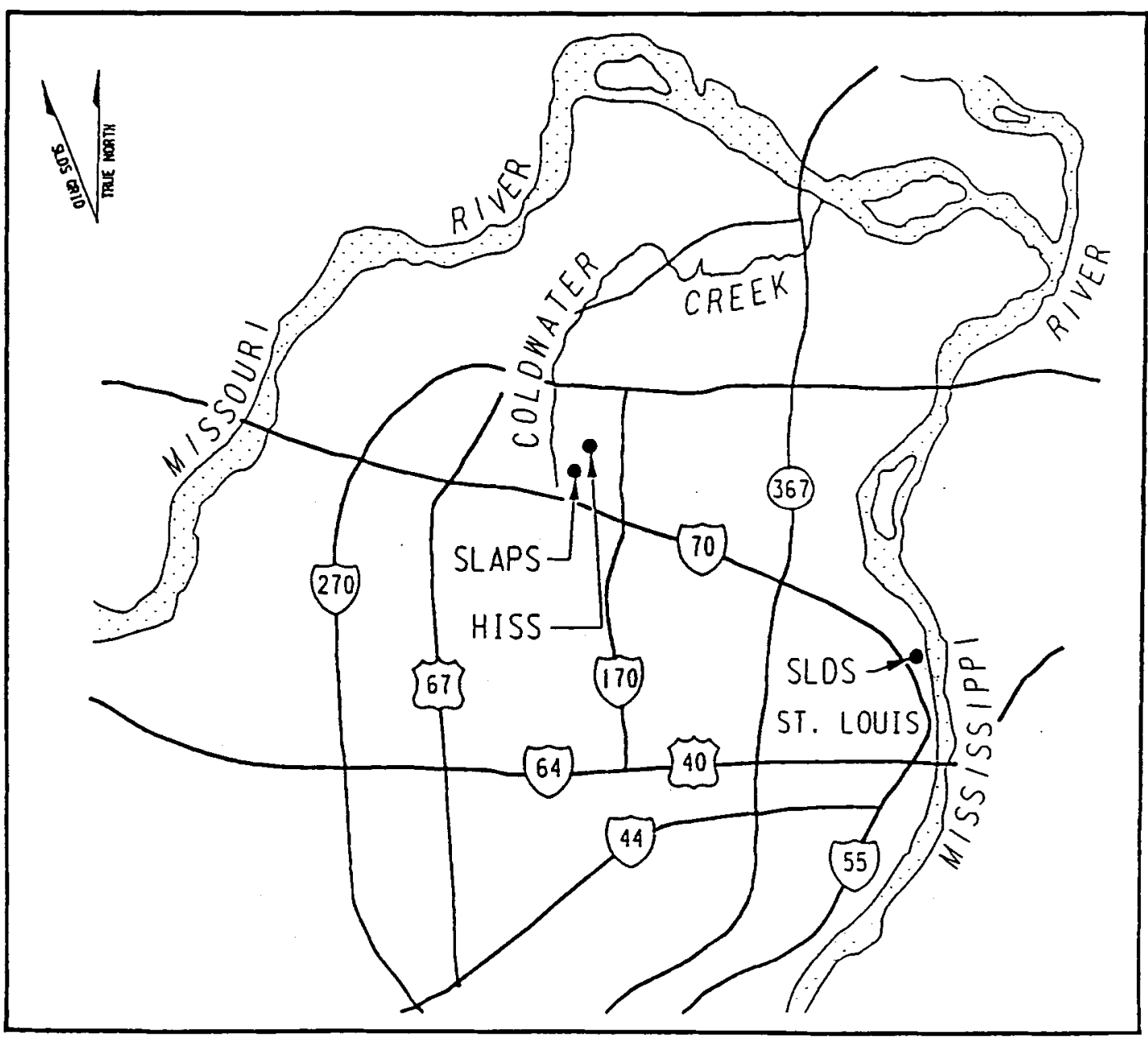

FIGURE 1 Location of FUSRAP Sites in the St. Louis, Missouri, Area 
goal of FUSRAP activity at the SLDS is to eliminate potential environmental hazards associated with residual contamination resulting from the site's use for government-funded uranium processing activities. Ultimately, DOE expects to implement a comprehensive cleanup effort at the SLDS to remove or otherwise control all such contamination that exceeds applicable cleanup guidelines. Implementation of comprehensive cleanup measures will be preceded by completion of a remedial investigation/feasibility study-environmental impact statement (RI/FS-EIS) process as required by the Comprehensive Environmental Response, Compensation, and Liability Act (CERCLA) and the National Environmental Policy Act (NEPA). The RI/FS-EIS process will conclude with the issuance of a record of decision (ROD) that will identify the selected remedy for all contamination present at the St. Louis Site. The RI/FS-EIS process is being conducted according to the Federal Facilities Agreement for the St. Louis Site. Thus, development and implementation of this action have been, and will continue to be, coordinated with the U.S. Environmental Protection Agency (EPA) Region VII and the state of Missouri. The DOE expects to propose its strategy for sitewide cleanup at the SLDS in calendar year 1994.

Examples of proprietor-initiated activities include building renovation and utility line maintenance efforts in locations that currently contain residual contamination. The DOE proposes to coordinate such activities with Mallinckrodt to ensure that contaminated material in subject areas is removed and safely stored, as necessary, to prevent uncontrolled relocation of contamination and to ensure that ultimate site cleanup objectives are not complicated by interim maintenance and construction activities implemented by Mallinckrodt. Accordingly, DOE is also proposing to create on-site, temporary storage capacity for the management of any contaminated wastes generated by these activities.

Implementation of the proposed removal action is expected to begin in the summer of 1991. Coordination with Mallinckrodt on site activities and the maintenance of associated storage facilities will continue, as necessary, until the sitewide remedial strategy, as identified in the ROD for the St. Louis Site, is implemented. At that time, all areas involved in the proposed removal action at the SLDS would be reevaluated and remediated, as necessary, to comply with the ROD for the St. Louis Site.

The proposed removal action is consistent with CERCLA, which requires that interim actions be consistent with and contribute (to the extent practicable) to the efficient performance of any anticipated final remedy. Interim action at the St. Louis Site, as proposed in this EE/CA, would satisfy these conditions because the contaminated materials would be consolidated in one location with appropriate controls to minimize potential human contact and migration to the environment. The action would also satisfy the requirements for interim actions under NEPA while an EIS is in progress, as identified in Title 40, Code of Federal Regulations (CFR), Part 1506.1.

In summary, the proposed removal action would address the goals of FUSRAP by containing the contamination at the SLDS and by ensuring the health and safety of workers in activities involving contaminated materials. This removal action should facilitate the eventual overall remedial action by controlling the volume of materials that will ultimately be disposed of, thereby controlling the cost of remediation. In addition, consolidating these materials in properly designed and managed locations within the SLDS will reduce or eliminate the risk of exposure to the materials. 


\section{SITE CHARACTERIZATION}

A brief description of the site and its setting is presented in Section 2.1, followed by a site history in Section 2.2. Section 2.3 provides available data that are relevant to this action, and site conditions that justify this removal action are presented in Section 2.4.

\subsection{SITE DESCRIPTION AND SETTING}

The SLDS is located in an industrial area on the eastern border of the city of St. Louis, about $90 \mathrm{~m}$ (300 ft) west of the Mississippi River (Bechtel National 1990b). The 18-ha (45-acre) site is owned by Mallinckrodt, Inc., and is currently used as a plant for the production of specialty chemicals. Numerous buildings and facilities cover a large portion of the site, and much of the remainder of the site is covered with asphalt or concrete (Bechtel National 1990b). Access to the site is currently limited to approximately 900 employees, 200 subcontracting construction workers, and visitors.

Water runoff from the SLDS is controlled by a system of combined sewers that directs excess flow to the river. The property has an extensive network of utility lines both above and below grade. Below-grade utilities include sewer, sprinkler, water, telephone, electric plant process piping, and natural gas lines. Overhead utilities include electric and telephone wires and plant process piping. The SLDS property is also traversed by three railroad line tracks.

Land use within a $1.6-\mathrm{km}$ (1-mi) radius of the SLDS reflects a mixture of public, agricultural, industrial, commercial, and residential activities (Bechtel National 1990b). The Mark Twain Freeway (I-70) is located along the western border of the SLDS.

Unconsolidated overburden materials are stratified clays, silts, sands, and gravels. A

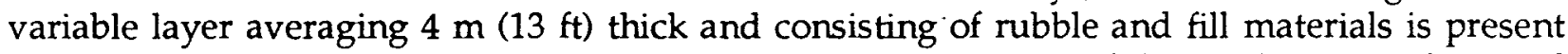
across most of the site. The concrete or asphalt that covers most of the site has altered natural runoff and recharge mechanisms. An extensive levee system parallel to the river has been constructed near the riverbank to protect the site from flooding. The SLDS is not located in the 100-year floodplain of the Mississippi River (Federal Insurance Administration 1979).

\subsection{SITE HISTORY}

The SLDS was used for the processing and production of various forms of uranium compounds and pure uranium metal from 1942 to 1957 . Work was conducted by the Mallinckrodt Chemical Works (currently Mallinckrodt, Inc.), under contracts with the Manhattan Engineer District.(MED) and Atomic Energy Commission (AEC), predecessors of DOE.

Plants 1, 2, 6, 6E, 7, and 10 (formerly Plant 4) were involved in uranium processing activities (Figure 2) (Bechtel National 1990b). Plants 1 and 2 were used for refining pitchblende and uranium oxide feeds in the initial plant operations from 1942 to 1945 . From 1948 through 1950 , these plants were decontaminated to meet AEC criteria in effect at that time. Plants $6,6 \mathrm{E}$, 7 , and 10 were used for uranium processing activities until cessation of MED/AEC work at the plant in 1957. Plant 6 was used in the processing of uranium-containing ore and in the 


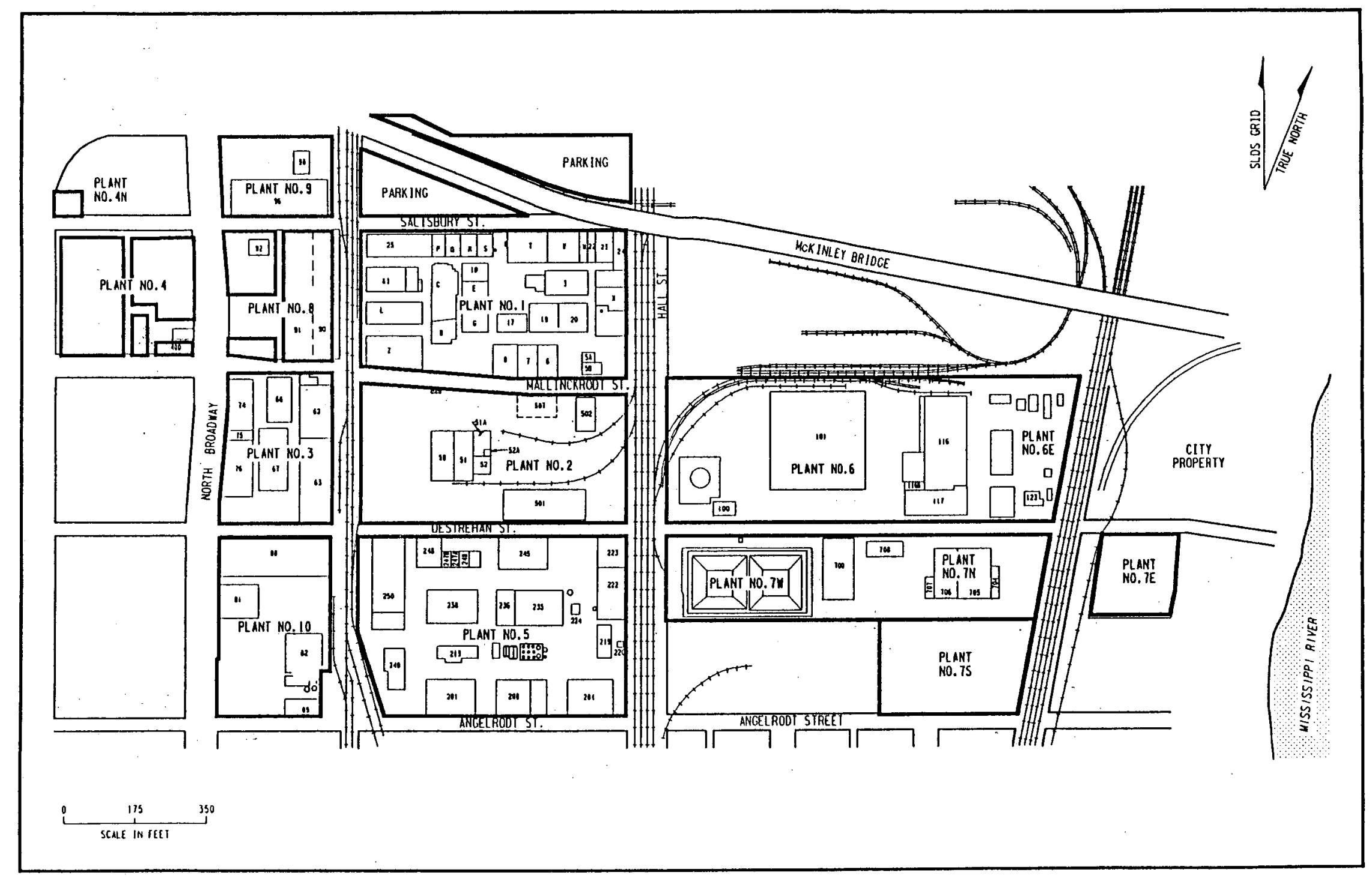

FIGURE 2 St. Louis Downtown Site 
production of uranium oxide; Plant $6 \mathrm{E}$ was designed to produce uranium metal; Plant 7 was used to produce and process uranium tetrafluoride and to store reactor cores; and Plant 10 was used as a metallurgical pilot plant for processing uranium metal. After cessation of MED/AEC work, these plants were decontaminated to meet AEC criteria in effect at that time.

Most contaminated buildings, equipment, and soils from Plant 10 (formerly Plant 4) and Plant 6E have been removed from the site. Some buildings that existed at Plants 6 and 10 at the time of MED/AEC operations have been razed, and some new buildings have been constructed at the former building locations (Bechtel National 1990c). Currently, plant buildings that were in use during MED/AEC operations are located in Plants 1, 2, 6, 7, and 10. Although decontamination actions in these buildings have been conducted in the past, many of these buildings do not meet current DOE radiological guidelines for surface contamination. Also, soil areas of Plant 5 have been found to contain radionuclide levels in excess of DOE guidelines, although historical data do not indicate that uranium processing occurred at Plant 5 (Bechtel National 1990b).

The main uranium-containing ore processed at the SLDS was African Congo pitchblende; however, some domestic ores were also processed (Bechtel National 1990a). The pitchblende and domestic ores used as feedstock for uranium compound production at the SLDS may also contain elevated levels of other elements, including arsenic, cobalt, copper, lead, manganese, molybdenum, nickel, selenium, vanadium, and zinc (Stokinger 1981; Dreesen et al. 1982).

\subsection{ANALYTICAL DATA}

A brief summary of available site characterization data related to the proposed removal action is given in Sections 2.3.1 and 2.3.2. Estimations of potential human health impacts associated with the proposed removal action are based on this information.

\subsubsection{Radiological Data}

Radiological surveys at the SLDS conducted by Bechtel National, Inc., and its radiological subcontractor, ThermoAnalytical/Eberline, were completed in 1989 (Bechtel National 1990b). The surveys were conducted in two phases. Two-hundred-eighteen boreholes were placed at the site during Phase 1 and Phase 2 investigations; most of the boreholes extended to

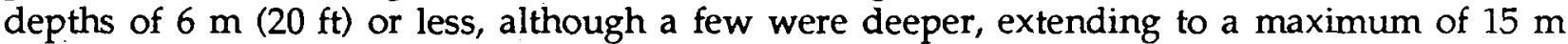
(50 ft) (Bechtel National 1990b). Radiological surveys and historical information on past processes at the SLDS indicate that contaminants include thorium-230, uranium-238, and radium-226. In addition, a source term analysis performed by Bechtel National, Inc., on a limited number of composite samples from the SLDS indicated the presence of other radionuclides, including protactinium-231 and actinium-227, at concentrations elevated above background levels (Liedle 1990).

Radiological surveys were conducted within and outside of buildings at the SLDS. The procedures and types of measurements used outside of buildings are briefly outlined in Section 2.3.1.1. The procedures and measurements within the buildings are discussed in

Section 2.3.1.2. All field measurements and laboratory results represent gross readings; that is, they have not been corrected for background levels. 


\subsubsection{Site Survey}

The radiological survey at the SLDS was based on a 15- by 15-m reproducible grid that allowed for identification of surveying and sampling locations. This grid was used to perform walkover gamma surveys and to collect soil samples.

Walkover gamma scans were conducted at the SLDS to identify areas of elevated gamma radiation. Surface and subsurface soil samplés were collected and analyzed for uranium-238, radium-226, thorium-232, and thorium-230. Survey measurements taken outside of the buildings at the SLDS are summarized in Table 1.

\subsubsection{Building Survey}

Radiological surveys of building surfaces and various drainage pathways were conducted to determine whether radioactivity was present at levels that exceed guidelines. All buildings used in past uranium processing operations were surveyed. Floors, walls, and ceilings were surveyed for removable alpha, total alpha, and beta-gamma contamination.

In addition to surface sampling, gamma exposure rates inside the plants at the SLDS were determined with a sodium-iodide, thallium-activated gamma scintillation detector. The average exposure rates indoors in some buildings were lower than the average outdoor background values because of the shielding inside buildings. Radon measurements were also taken in each of the buildings. Measurements taken inside of the buildings at the SLDS are summarized in Table 2.

TABLE 1 Summary of Radiological Characteristics Outside of Buildings at the SLDS

\begin{tabular}{lccc}
\hline \multicolumn{1}{c}{ Measurement } & Unit & Range & Average \\
\hline Gamma radiation exposure rate & $\mu R / h$ & $4.8-26^{\mathrm{a}}$ & 15 \\
& & & \\
Radionuclide concentration in soil ${ }^{\mathrm{b}}$ & $\mathrm{pCi} / \mathrm{g}$ & & $1.0-33,000$ \\
$\quad$ Uranium-238 & & $0.2-5,400$ & 20 \\
Radium-226 & & $0.2-14,000$ & 47 \\
Thorium-230 & $0.3-440$ & 3.7 \\
Thorium-232 & & \\
\hline & & & \\
a Average range. & & \\
bSimple averages were used. & & \\
Source: Bechtel National 1990b. &
\end{tabular}


TABLE 2 Summary of Radiological Characteristics Inside of Buildings at the SLDS

\begin{tabular}{lccccc}
\hline & \multicolumn{2}{c}{$\begin{array}{c}\text { Exposure Rate } \\
(\mu \mathrm{R} / \mathrm{h})\end{array}$} & & \multicolumn{2}{c}{$\begin{array}{c}\text { Radon Concentration } \\
(\mathrm{pCi} / \mathrm{L})\end{array}$} \\
\cline { 2 - 3 } \cline { 5 - 6 } Building & Range & Average & & Range & Average \\
\hline K1E & $18-200$ & 48 & & $1.7-73$ & 23 \\
25 & $6.0-72$ & 7.0 & & $0.040-0.30$ & 0.10 \\
50 & $6.0-10$ & 6.0 & & $0.040-0.10$ & 0.050 \\
51 & $6.0-32$ & 16 & & $0.10-0.30$ & 0.20 \\
$51 \mathrm{~A}$ & $6.0-18$ & 10 & & $0.80-1.1$ & 0.95 \\
52 & $8.0-34$ & 10 & & $0.040-0.040^{\mathrm{a}}$ & $0.040^{\mathrm{a}}$ \\
$52 \mathrm{~A}$ & $17-30$ & 21 & & $0.50-0.60$ & 0.55 \\
81 & $2.0-6.0$ & 4.0 & & $0.10-0.30$ & 0.20 \\
82 & $6.0-10$ & 6.0 & & $0.10-0.50$ & 0.30 \\
100 & $6.0-7.0$ & 6.0 & & $0.20-0.40$ & 0.30 \\
116 & $5.0-10$ & 6.0 & & $0.040-0.50$ & 0.30 \\
$116 \mathrm{~B}$ & $6.0-20$ & 9.0 & & -5 & $-\mathrm{b}$ \\
117 & $5.0-29$ & 6.0 & & $0.10-1.0$ & 0.55 \\
700 & $5.0-13$ & 6.0 & & $0.040-0.040$ & 0.040 \\
704 & $6.0-8.0$ & 6.0 & & $0.20-0.40$ & 0.30 \\
705 & $3.0-10$ & 5.0 & & $0.040-0.25$ & 0.16 \\
706 & $4.0-6.0$ & 5.0 & $0.040-0.12$ & 0.050 \\
707 & $4.0-6.0$ & 5.0 & $0.040-0.40$ & 0.20 \\
708 & $5.0-21$ & 7.0 & $0.040-0.40$ & 0.040 \\
\hline
\end{tabular}

${ }^{a}$ One measurement taken.

${ }^{b}$ No radon measurement taken in this building.

Source: Bechtel National 1990b.

\subsubsection{Chemical Data}

Chemical sampling of soils was primarily conducted in known radiologically contaminated areas at the SLDS (Bechtel. National 1990b). Sampling objectives included (1) determination of the existence of waste classified as hazardous under the Resource Conservation and Recovery Act (RCRA), as defined in 40 CFR 261; (2) investigation of whether radiologically contaminated wastes are also contaminated with hazardous chemicals; and (3) determination of appropriate health and safety measures necessary for remedial action activities. Chemical analyses were not conducted on samples obtained from building interiors.

Both composite soil samples and samples from discrete depth intervals were obtained in various plant areas known to be radiologically contaminated (i.e., Plants 1, 2, 5, 6, 6E, 7, and 10). Samples were obtained from 108 of the 218 boreholes that were used for radiological investigations; most samples were obtained from depths of $6 \mathrm{~m}(20 \mathrm{ft})$ or less. During the two 
sampling phases conducted at the various plant areas, 63 borehole samples were tested for RCRA characteristics; samples from approximately 100 boreholes were tested for metals; 56 borehole samples were tested for semivolatile organic compounds; and samples from 23 boreholes were tested for volatile organic compounds.

Three of the 63 composite samples failed the RCRA extraction procedure (EP) toxicity test for lead. Soil from one borehole in Plant 1 and two boreholes in Plant 6 had values of 21, 19 , and $6.3 \mathrm{mg} / \mathrm{L}$ lead, respectively, as compared with the regulatory limit of $5 \mathrm{mg} / \mathrm{L}$.

Soil sampling results also indicated that several metals and polycyclic aromatic hydrocarbons (PAHs), a class of semivolatile compounds, were present at elevated levels (see Table 3).

TABLE 3 Summary of Metal and PAH Concentrations in Soil at the SLDS

\begin{tabular}{lcc}
\hline \multicolumn{1}{c}{ Chemical } & $\begin{array}{c}\text { Range } \\
(\mathrm{mg} / \mathrm{kg})\end{array}$ & $\begin{array}{c}\text { Average } \\
(\mathrm{mg} / \mathrm{kg})\end{array}$ \\
\hline Antimony & $9.3-3,200$ & 39 \\
Arsenic & $16-200$ & 34 \\
Beryllium & $0.80-10$ & 1.2 \\
Cadmium & $0.80-44$ & 2.1 \\
Lead & $17-32,000$ & 490 \\
Nickel & $3.3-230$ & 26 \\
Selenium & $16-1300$ & 84 \\
Thallium & $16-320$ & 42 \\
Uranium & $3.0-280,000$ & 2,400 \\
Total PAHs & $8.2-1,300$ & 89 \\
cPAH $^{\mathrm{a}}$ & $3.2-440$ & 32 \\
\hline
\end{tabular}

${ }^{\text {a }}$ AHs $=$ total polycyclic aromatic hydrocarbons.

${ }^{b} \mathrm{CPAHs}=$ potentially carcinogenic PAHs.

Source: Bechtel National 1990b. Data are combined for Phase 1 and Phase 2 sampling; metal data are based on 166 composite and discrete soil samples; and PAH data are based on 56 composite samples. Concentration values have been rounded to two significant figures. 


\subsection{SITE CONDITIONS THAT JUSTIFY A REMOVAL ACTION}

The threats posed by radioactive and chemical contamination at the SLDS are of a nontime-critical nature; that is, no immediate risk to human health or the environment currently exists at this plant that would necessitate emergency cleanup within six months. However, because extensive radiological contamination exists at the SLDS, most site activities initiated by site proprietors (e.g., excavation or renovation) could result in the generation of contaminated waste; therefore, the proposed removal action at the SLDS is warranted to prevent the inadvertent spread of contamination. Further, this action would minimize the potential for increased exposures and control the overall cost of remediation of the contaminated wastes at the St. Louis Site. 


\section{REMOVAL ACTION OBJECTIVES}

The DOE has determined that soils and numerous structures across the SLDS are contaminated above DOE guidelines for radioactivity. Despite existing contamination, no immediate risk to human health or the environment exists with current land use at the SLDS. Many operational and maintenance activities implemented by site proprietors, however, could result in the generation of contaminated materials and lead to inadvertent spread of and exposure to these materials. The DOE is proposing to support these site activities to (1) minimize inadvertent exposure to contaminated materials and (2) allow for the consolidation of the resultant contaminated materials at engineered interim waste storage areas within the plant. Because the number and nature of waste-generating activities would depend largely on the needs of site proprietors, it is difficult for DOE to estimate the total volume of waste that might be generated. Hence, the total interim storage capacity required cannot be specifically quantified at this time. It will, however, be developed in accordance with regulatory requirements. The storage areas may be inside buildings or may consist of exterior engineered piles. Potential activities to be conducted by site proprietors within the scope of this EE/CA, include excavation (e.g., for new building construction, subsurface utility repair, road improvements, fence installation or repair, and sewer and sump repair); building decontamination, demolition or remodeling; and roof repair.

The proposed action would allow DOE to minimize inadvertent spreading of contaminants and ensure the proper disposition of waste, thus contributing to the overall remedy selected for the final disposal of all contaminated materials found at the St. Louis Site.

Specific objectives are as follows:

- Support of SLDS proprietors in the performance of plant activities involving movement or displacement of contaminated materials;

- Waste minimization through segregation and/or decontamination; for example, planing of contaminated wood surfaces before removal of such materials and scraping or blasting of contaminated steel-pipe surfaces, structural steel, and concrete;

- Consolidation of contaminated material in indoor or outdoor controlled areas;

- Minimization of potential health hazards to on-site personnel performing site activities; and

- Collection and analysis of soil samples taken after the response action is implemented to confirm that decontaminated areas meet applicable guidelines.

\subsection{STATUTORY AUTHORITY}

Authority for responding to releases or threats of releases from a hazardous waste site is addressed in Section 104 of CERCLA. Under CERCLA Section 104(b), DOE is authorized to 
investigate, survey, test, or gather other data required to identify the existence, extent, and nature of contaminants, including the extent of danger to human health and the environment. In addition, DOE is authorized to undertake planning, engineering, and other studies or investigations appropriate to directing response actions that prevent, limit, or mitigate potential risks associated with the site. As a successor of the AEC, DOE derives its authority from the Atomic Energy Act for response actions at sites that are not federally owned, such as the SLDS.

\subsection{COMPLIANCE WITH APPLICABLE OR RELEVANT AND APPROPRIATE REQUIREMENTS}

Response actions at the SLDS would be carried out in accordance with applicable or relevant and appropriate federal and state requirements (ARARs). Applicable requirements are those for which the jurisdictional prerequisites are specifically met by the proposed action or site circumstances. Relevant and appropriate requirements are those that address problems or situations sufficiently similar to those encountered at the site in question that their use is well-suited to the particular site. A determination of applicability is made for the requirement as a whole, whereas a determination of relevance and appropriateness may be made for specific portions of a requirement. Any standard, requirement, criterion, or limitation under any federal or state environmental law or state facility siting law may be considered either applicable or relevant and appropriate to a specific action at a site.

Requirements that may be pertinent to the proposed action at the SLDS are presented in Appendix A. The preliminary identification of potential ARARs for the proposed action is based on the nature of the contamination (primarily radioactively contaminated soils and structures) and the location of the plant. Potential ARARs may include RCRA requirements for the management of hazardous wastes. Three of 63 composite soil samples from the SLDS failed the EP toxicity test for lead (Bechtel National 1990b), meaning that the prerequisite for definition as characteristic hazardous waste could be met for certain site material (most of the soil analyzed from the SLDS did not exhibit hazardous waste characteristics). If hazardous waste is encountered during the course of site activities, this waste would be handled and stored according to the substantive requirements of RCRA.

In addition to ARARs, guidelines or standards that have not been promulgated may also have a direct bearing on the proposed action. These are identified as "to-be-considered" (TBC) requirements and include certain DOE guidelines. The DOE guidelines with which the proposed action will comply include limits for residual concentrations of radium and thorium in soil, which have been adopted from standards promulgated by EPA. The limits for these radionuclides are $5 \mathrm{pCi} / \mathrm{g}$ averaged over a $100-\mathrm{m}^{2}$ area for the surface $15 \mathrm{~cm}$ of soil and $15 \mathrm{pCi} / \mathrm{g}$ for each 15-cm increment below the surface (DOE Order 5400.5). Available data indicate that radionuclide concentrations present at the SLDS exceed these guidelines (see Table 1). The DOE guidelines for structural material to be released for use without radiological restriction are $5,000 \mathrm{dpm} / 100 \mathrm{~cm}^{2}$ average, $15,000 \mathrm{dpm} / 100 \mathrm{~cm}^{2}$ maximum, and $1,000 \mathrm{dpm} / 100$ $\mathrm{cm}^{2}$ removable for uranium and beta-gamma emitters. These limits, which have been adopted from U.S. Nuclear Regulatory Commission (NRC) criteria, are to be applied separately for alpha and beta-gamma activity (DOE Order 5400.5). Survey results for the SLDS indicate that the maximum readings obtained on the roofs and buildings exceed these DOE limits. In addition to the criteria provided in DOE Order 5400.5, the proposed action will also comply with a sitespecific guideline for uranium-238 in soil. This guideline is currently being developed as part of the ongoing RI/FS process for the St. Louis Site. On the basis of preliminary calculations, in 
which DOE's as low as reasonably achievable (ALARA) process was incorporated, a concentration of $50 \mathrm{pCi} / \mathrm{g}$ of uranium-238 has been identified as a target limit that will not result in incremental adverse human health impacts for plausible future land uses.

The DOE would comply with all pertinent environmental requirements to ensure the protection of human health and the environment during implementation of the proposed removal action. Appropriate standards from the Occupational Safety and Health Administration Act and other employee protection laws and guidelines would be followed to ensure worker protection during implementation. 


\section{REMOVAL ACTION ALTERNATIVES}

Removal action alternatives were identified by considering relevant technologies that might be implemented. The procedure and rationale for developing alternatives used in this document are consistent with those given in the National Oil and Hazardous Substances Pollution Contingency Plan and EPA guidance regarding removal actions. The alternatives for the proposed action are as follows:

Alternative 1: No action until implementation of the ROD;

Alternative 2: Decontamination and/or removal of contaminated structural material and excavation of contaminated soil, with interim storage and/or disposal off-site; and

Alternative 3: Decontamination and/or removal of contaminated structural material and excavation of contaminated soil, with interim storage within the SLDS.

The no-action alternative does not involve any management of contamination during ongoing site activities; Alternatives 2 and 3 involve removal of contamination with DOE support and supervision prior to maintenance or construction activities, but with consolidation of generated contaminated materials at a facility outside of the SLDS for Alternative 2, and consolidation and monitoring of the same materials within the SLDS for Alternative 3. These three alternatives are compared in Sections 4.1 for their effectiveness, implementability, and cost; the preferred alternative is identified in Section 4.2.

The effectiveness of an alternative is defined by its ability to ensure protection of and minimize impacts to human health and the environment. Implementability of an alternative is defined by its technical feasibility, availability, and administrative feasibility. Administrative feasibility considerations address the potential of a proposed action to achieve response objectives and to satisfy state and local agency concerns, including permitting and interagency cooperation, public and occupational safety, impacts on land use, compliance with policies and requirements, and public acceptance.

\subsection{COMPARATIVE ANALYSIS}

Alternative 1 does not allow for the control of contaminated materials and could contribute to the spread of contamination. In the near term, no direct cost is incurred by Alternative 1; however, the cost for implementing the overall remedial action for permanent disposal of the contaminated materials could be appreciably increased because inadvertent spreading of the waste would lead to increases in volume.

Alternative 2 is difficult to implement because an interim storage or disposal facility outside the SLDS is currently unavailable. Therefore, a considerable delay in the implementation of any action would occur because of the time associated with siting and preparing a suitable interim storage or disposal facility. In addition, a larger cost would be incurred in the implementation of this alternative for handling and transporting the materials to said facility. 
Alternative 1 does not meet removal action objectives because it would not aid in minimizing potential adverse impacts to human health and the environment. Alternative 2 does not meet removal action objectives because it cannot be readily implemented in the near term. Alternative 3, however, satisfies removal action objectives in the ways discussed below.

Alternative 3 can be implemented because it involves the use of technically feasible methods (i.e., decontamination and excavation) for the removal of contaminated materials. Consolidation of the displaced contaminated waste at an interim storage area within the SLDS is also technically feasible. Decontamination of structural materials could reduce waste mobility and reduce, if not eliminate, human contact with and/or disturbance of contaminated surfaces. Excavation would significantly reduce waste mobility subsequent to implementation; its effectiveness has been demonstrated during past removal actions at other FUSRAP sites. Access restrictions (i.e., barricades and fences) would reduce waste mobility and limit human or animal contact. Interim storage is technically feasible and would reduce waste mobility. Its effectiveness has been demonstrated at other interim storage facilities such as the HISS in suburban St. Louis. Monitoring and maintenance of interim storage would be conducted by DOE to ensure proper functioning and continued effectiveness.

Implementation of Alternative 3 is administratively feasible because (1) DOE has the cooperation of the site proprietors in conducting the proposed action and (2) DOE is coordinating activities with EPA Region VII and the state of Missouri. Alternative 3 is a proactive approach on the part of $\mathrm{DOE}$ to control the contamination that currently exists at the SLDS and to minimize exposures to workers involved in SLDS activities.

Costs would be incurred in the near term for the decontamination of building surfaces, excavation of soil, consolidation of the contaminated materials, and preparation of interim storage areas. The cost estimate for Alternative 3 includes the costs for subcontracts, engineering, environmental health and safety support, procurement, office overhead, and contingencies. Because the number and nature of activities depend on the needs of site proprietors, the total waste volume generated in any given year cannot be established beforehand. However, a cost of approximately $\$ 460,000$ can be expected, assuming generation of $380 \mathrm{~m}^{3}\left(500 \mathrm{yd}^{3}\right)$ of waste. In this estimate, a possible mix of activities (i.e., roof repair, utility repair, and soil excavation) was considered, with emphasis on soil excavation. In addition, approximately $\$ 295,000$ would be required to prepare an initial interior interim storage area to receive waste and to maintain such an area for a year. Additional costs associated with the operation and maintenance (e.g., monitoring) of the storage area are expected to be minimal. Removal and interim storage activities would be implemented in compliance with ARARs (see Section 3.2 and Appendix A).

The potential environmental consequences associated with Alternative 3 include temporary disturbance of soils and temporary increases in airborne radioactive particulates. Mitigative measures and good engineering practices, such as wetting exposed surfaces and limiting the work area, would be implemented during the action periods of Alternative 3 to minimize these potential impacts. The long-term environmental consequences associated with Alternative 3 would be beneficial because the radioactive materials would be removed and consolidated at an interim storage area remote from human and animal contact as well as from environmental forces that could further disperse the contamination. 


\subsection{IDENTIFICATION OF THE PREFERRED ALTERNATIVE}

On the basis of the comparative analysis of removal action alternatives presented in Section 4.1, Alternative 3 has been identified as a technically feasible, timely, and cost-effective alternative that is more protective of human health or welfare and the environment than the other alternatives and that meets the needs of SLDS proprietors. Therefore, the recommended response action for the SLDS is Alternative 3 - decontamination with subsequent removal of contaminated structural material, removal (excavation) of contaminated soils, and consolidation and interim storage of such displaced materials in prepared buildings or engineered exterior piles. 


\section{DESCRIPTION OF THE PREFERRED ALTERNATIVE}

The proposed removal action involves the consolidation of contaminated waste resulting from site activities (i.e., removal of structural materials and excavation of soils) and the placement of these wastes into prepared areas for controlled interim storage inside one or more buildings or at an outdoor area. Currently, site proprietors have made Buildings 116 and 117 available to DOE for initial interim storage. For the purpose of this action, contamination is defined as residual soil levels exceeding $5 \mathrm{pCi} / \mathrm{g}$ of radium-226 and thorium- 230 when averaged over a $100-\mathrm{m}^{2}\left(1076-\mathrm{ft}^{2}\right)$ area for the first $15 \mathrm{~cm}(6 \mathrm{in}$ ) of soil below the surface; concentrations exceeding $15 \mathrm{pCi} / \mathrm{g}$ when averaged over this area for any 15-cm-thick (6-in.-thick) soil layer below the surface layer; and structural surfaces contaminated with beta-gamma emitters exceeding $5,000 \mathrm{dpm} / 100 \mathrm{~cm}^{2}$ average, $15,000 \mathrm{dpm} / 100 \mathrm{~cm}^{2}$ maximum, and $1,000 \mathrm{dpm} / 100 \mathrm{~cm}^{2}$ removable (DOE Order 5400.5). Soils containing concentrations of uranium-238 exceeding 50 $\mathrm{pCi} / \mathrm{g}$ would be considered for excavation; concentrations equal to or less than $50 \mathrm{pCi} / \mathrm{g}$ in soil can be considered protective of human health for all plausible future land uses at the SLDS (see Section 3.1). In addition, it is not anticipated that wastes. considered to be hazardous under RCRA would be generated; however, prior to excavation of areas suspected to contain such materials, sampling would be conducted and confirmatory analyses would be performed via the toxicity characteristic leaching procedure test, which has replaced the EP toxicity test. If the presence of RCRA waste is confirmed, such material; if excavated, would be managed according to the substantive requirements of RCRA. The proposed action would include the following activities:

- Construction of a facility to clean tools and equipment used in decontamination and excavation activities. The facility would consist of an impermeable geomembrane liner and splash curtains to retain the water used to clean tools and equipment. All water collected would be recycled. The recycled water system would consist of a collection sump, sand filters, and storage tank. In addition, a berm would be constructed around the facility, and an impermeable geomembrane cover would be placed over the facility during off hours to prevent the infiltration of precipitation and runon. This water would be discharged in accordance with the existing agreement between the SLDS and the metropolitan sanitary district for which a National Pollutant Discharge Elimination System permit is in place.

- Preparation of an initial interim storage facility (i.e., Building 116) to receive radiologically contaminated materials (see Figure 3 ). This action would include, but would not be limited to, the following activities: setting up access restrictions to isolate work and storage areas from employees, replacing window panes and repairing roofing membranes, and controlling the spread of contamination within the building by sealing the concrete floor and interior walls. In addition to preparing Building 116 to receive contaminated wastes, the following activities would be undertaken to monitor and mitigate the spread of contamination. Contaminated materials would be kept moist and covered with a geomembrane to mitigate the spread of airborne particulates. Interior and exterior environmental monitoring of Building 116 would be implemented. As additional capacity is needed, other buildings would be prepared and monitored in a similar manner. 


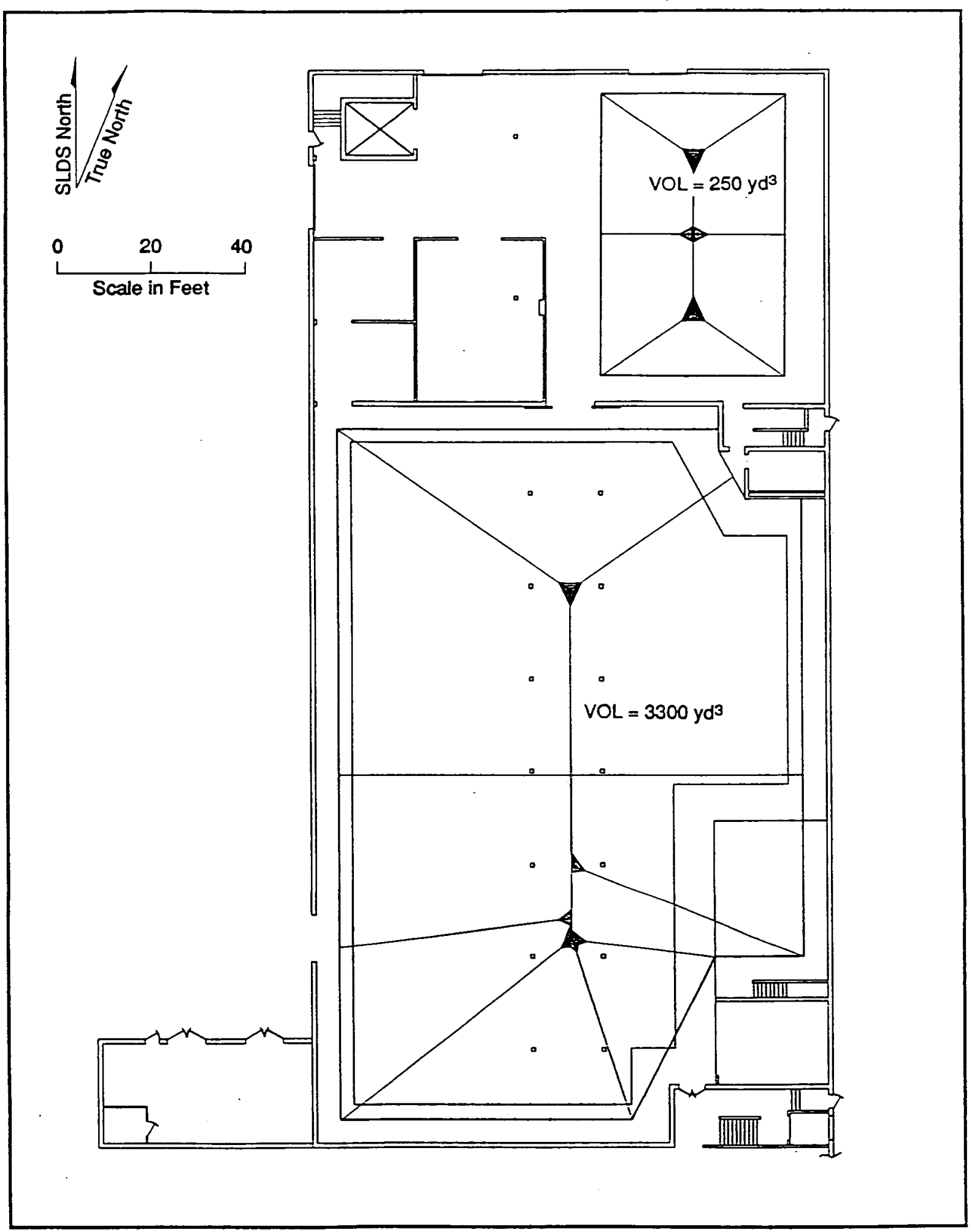

FIGURE 3 Potential Interim Storage Plan for the First Floor of Building 116 
- Decontamination of building surfaces by using appropriate techniques and conducting a survey of the rubble to segregate contaminated from clean materials, to the extent practicable.

- Excavation of contaminated soils for construction and maintenance activities. Excavation of areas with deep, extensive soil contamination that is accompanied by volumes exceeding immediately available storage capacity would be determined on a case-by-case basis. If determined to be appropriate, additional storage capacity would be created to accommodate such material. The cleanup of all remaining contaminated areas at the SLDS would take place after the ROD is issued for the St. Louis Site. The ROD will identify the final remediation for permanent disposal of all contaminated waste.

- Analysis of soil samples taken after the action to confirm that cleanup is in compliance with applicable or relevant and appropriate requirements.

- Performance of restoration activities in certain action areas. Through the cooperation of and consultation with site proprietors, a determination would be made on a case-by-case basis for any needed restoration to be performed by DOE.

- Monitoring of the interim storage area (i.e., Building 116) to ensure that conditions meet regulatory requirements. This action would include monitoring for gamma radiation levels, radon releases, and groundwater quality (for exterior storage only). Any building housing a storage facility would be sealed to prevent inadvertent escape of contamination and unauthorized access. For an exterior pile, the area would be graded and stabilized; monitoring wells would be installed; and a security fence would be employed as a barrier. The proposed action includes various measures that would reduce the potential for adverse effects on human health and the environment. These measures include components of both planning and implementation. Major mitigative measures associated with the action are summarized in Table 4. All activities would be carried out in compliance with DOE safety regulations, the program health and safety plan, and other applicable requirements. Radiation protection and monitoring would be provided in the workplace for all workers. 
TABLE 4 Major Mitigative Measures for the Proposed Action

\begin{tabular}{ll}
\hline \multicolumn{1}{c}{ Factor } & \multicolumn{1}{c}{ Features } \\
\hline Dust control & $\begin{array}{l}\text { Dust would be controlled by using wet methods during } \\
\text { excavations. }\end{array}$ \\
Worker protection & $\begin{array}{l}\text { An operational environmental safety and health plan would } \\
\text { be in place. If necessary, protective equipment would be } \\
\text { used. Good housekeeping practices would be used, and } \\
\text { radiation would be monitored. }\end{array}$ \\
Environmental monitoring & $\begin{array}{l}\text { The interim storage area (i.e., Building 116) would be } \\
\text { monitored for gamma radiation levels and radon releases. }\end{array}$ \\
Groundwater near any exterior storage area would be \\
monitored. \\
Contaminated materials would be placed in an engineered \\
storage area that has a bottom liner and cover. The area \\
would be monitored for radon and external gamma \\
radiation. Access to the storage area would be restricted. \\
In addition, most storage is expected to be inside a \\
building.
\end{tabular}




\section{HEALTH AND ENVIRONMENTAL IMPACTS OF THE PREFERRED ALTERNATIVE}

Because mitigative measures (i.e., use of barricades and dust control) would be taken to control contaminant movement and to isolate work areas while site activities are conducted, the radiation dose and chemical intake of individuals other than removal action workers (e.g., site workers) would be minimal. Therefore, calculations were limited to estimations of potential radiation doses and chemical risks for removal action workers involved in the proposed action. Currently, the number of activities planned by site proprietors in a given year cannot be specified; thus, the radiological dose and chemical risk estimates for a worker conducting the proposed action were made on the basis of a conservative assumption of an exposure of 2000 work hours, that is, one full work year.

\subsection{WORKER RADIATION DOSE AND RISK}

To estimate the potential radiological dose to a removal action worker, it was assumed that the worker performs activities outside the buildings (e.g., excavation) half of the time and inside the buildings (e.g., renovation or decontamination) the remainder of the time. This worker would incur doses primarily from external gamma exposure and inhalation of radionuclides. Respiratory protective equipment would be used, as appropriate (e.g., in highly contaminated areas), to minimize inhalation exposure when conducting activities.

Exposure to external gamma radiation would occur both inside and outside buildings. The radiation dose received from external gamma exposure was calculated by multiplying the length of time an individual would be exposed (i.e., $1000 \mathrm{~h}$ outside and $1000 \mathrm{~h}$ inside) by the average measured gamma exposure rate. Highest average exposure rates of $15 \mu \mathrm{R} / \mathrm{h}$ outdoors and $48 \mu \mathrm{R} / \mathrm{h}$ indoors (see Tables 1 and 2 ) in contaminated site areas were used.

The worker could also be exposed to airborne particles via inhalation. It is expected that respiratory protective equipment would be used during activities inside buildings that could generate contaminated dust (e.g., decontamination of structural surfaces). Therefore, exposure via this pathway has not been quantified. However, the worker could inhale particulates resuspended from soil during outdoor activities, such as excavation, during which respiratory protective equipment may not be used. To estimate this potential inhalation exposure, average soil concentration values for the SLDS were used, including those in Table 1 (Bechtel National 1990b; Liedle 1990). A mass loading factor of $2 \times 10^{-4} \mathrm{~g} / \mathrm{m}^{3}$ and an inhalation rate of $1.2 \mathrm{~m}^{3} / \mathrm{h}$ (International Commission on Radiological Protection 1975) were used. Dose conversion factors were obtained from Gilbert et al. (1989).

Potential worker exposure via inhalation of radon-222 and its progeny was also evaluated for this assessment. The highest average radon concentration measured in the buildings is $23 \mathrm{pCi} / \mathrm{L}$ in Building $\mathrm{K} 1 \mathrm{E}$; the concentrations measured in other buildings are much

lower (see Table 2). For this assessment, it was assumed that a worker spends time in each of the buildings and is exposed to an average radon-222 concentration of $2 \mathrm{pCi} / \mathrm{L}$. Using an indoor equilibrium factor of 0.5 , this radon-222 concentration corresponds to a radon decay product concentration of 0.01 working level (WL).

The annual radiation exposures and resultant risks of cancer induction for the hypothetical decontamination worker are given in Table 5. The radiation dose from external 
TABLE 5 Estimated Radiation Exposures and Health Risks to a Hypothetical Decontamination Worker

\begin{tabular}{|c|c|c|c|}
\hline Exposure Pathway & $\begin{array}{l}\text { Annual } \\
\text { Exposure }\end{array}$ & Risk Factor & Risk \\
\hline \multicolumn{4}{|l|}{ External gamma } \\
\hline outdoor & 14 mrem & $6.0 \times 10^{-7} / \mathrm{mrem}^{\mathrm{a}}$ & $8.4 \times 10^{-6}$ \\
\hline indoor & 46 mrem & $6.0 \times 10^{-7} / \mathrm{mrem}^{\mathrm{a}}$ & $2.8 \times 10^{-5}$ \\
\hline $\begin{array}{l}\text { Inhalation of resuspended } \\
\text { radionuclides }\end{array}$ & 51 mrem & $6.0 \times 10^{-7} / \mathrm{mrem}^{\mathrm{a}}$ & $3.1 \times 10^{-5}$ \\
\hline $\begin{array}{l}\text { Inhalation of radon-222 } \\
\text { decay products }\end{array}$ & $0.059 \mathrm{WLM} / \mathrm{yr}$ & $3.5 \times 10^{-4} / \mathrm{WLM}^{\mathrm{c}}$ & $2.1 \times 10^{-5}$ \\
\hline \multicolumn{3}{|l|}{ Total risks } & $8.8 \times 10^{-5}$ \\
\hline \multicolumn{4}{|c|}{ aisk of cancer induction based on information given in EPA 1989.} \\
\hline \multicolumn{4}{|c|}{$\begin{array}{l}{ }^{b} \text { Based on an exposure time of } 1000 \mathrm{hr} \text {; one working-level month (WLM) is } \\
\text { the exposure to } 1 \mathrm{WL} \text { for } 170 \text { hours. }\end{array}$} \\
\hline
\end{tabular}

gamma exposure and inhalation of contaminated dust is estimated to be $111 \mathrm{mrem} / \mathrm{yr}$. The radon decay product exposure associated with the proposed action is $0.059 \mathrm{WLM} / \mathrm{yr}$. This radon decay product exposure corresponds to an effective dose equivalent of $59 \mathrm{mrem} / \mathrm{yr}$, on the basis of dose conversion factors given by the International Commission on Radiological Protection (1981). Thus, the total radiation dose to the hypothetical worker is estimated to be $170 \mathrm{mrem} / \mathrm{yr}$, which is well below the DOE occupational dose limit of $5000 \mathrm{mrem} / \mathrm{yr}$ given in DOE Order 5480.11. This radiation exposure would result in an annual incremental lifetime radiological risk of $8.8 \times 10^{-5}$ (i.e., the risk of cancer induction over the remainder of the worker's lifetime from this one year of radiation exposure). For purposes of comparison, exposure to natural sources of radiation (i.e., radon, terrestrial radiation, and cosmic rays) results in an effective dose equivalent of about $300 \mathrm{mrem} / \mathrm{yr}$ (National Council on Radiation Protection and Measurements 1987).

\subsection{WORKER CHEMICAL INTAKE AND RISK}

The inhalation intakes of metals and PAHs for a worker conducting a removal action at the SLDS were estimated by using the same duration of exposure (i.e., $2000 \mathrm{~h} / \mathrm{yr}$ ), mass loading factor, and inhalation rate as were used for the radiological dose calculations. Metals to be evaluated were selected on the basis of presence above background and degree of toxicity; intake was estimated for all chemical constituents listed in Table 3. On the basis of these intake estimates, a hazard index (i.e., an estimate of the potential for noncarcinogenic toxicity) for worker exposure was calculated. The hazard index for this assessment was based on a 
comparison of site chemical levels with occupational standards (Occupational Safety and Health Administration 1989). A hazard index of less than 1 indicates that the exposure would not likely result in deleterious effects. Hazard indexes much smaller than 1 (i.e., less than 0.01) indicate that noncarcinogenic toxicity is quite unlikely. The hazard index calculated for worker exposure to average soil levels of metals and PAHs was 0.004 for a worker conducting the proposed removal action. This level indicates that no significant risk of noncarcinogenic effects due to inhalation of resuspended chemical contaminants would be incurred by the removal action workers.

Several of the metals (i.e., arsenic, cadmium, lead, and nickel) and PAHs present in site soil are also classified as potential carcinogens by EPA. Again, on the basis of average soil levels of these substances, the inhalation carcinogenic risk for a removal action worker was estimated to be $5.0 \times 10^{-7}$. Lead was not included in the above calculation because of the unavailability of a risk factor for carcinogenic effects. However, toxicity data indicate that noncarcinogenic effects of lead occur at lower exposure levels than carcinogenic effects (Agency for Toxic Substances and Disease Registry 1990); therefore, the hazard index calculation including lead is considered a primary indicator for this evaluation.

In contrast to the metals, a potential also exists for carcinogenicity from dermal exposure to PAHs. The carcinogenic risk associated with dermal exposure to the average level of carcinogenic PAHs in soils at the SLDS, assuming that no protective clothing is used and that the hands and upper arms are exposed, was estimated as $3.4 \times 10^{-5}$ for a worker conducting the removal action.

\subsection{PUBLIC HEALTH IMPACTS}

Although the estimated radiological doses and chemical intakes for removal action workers outside and inside of buildings at the SLDS are considerably below federal guidelines, these doses could be reduced even more by good engineering practices (e.g., effective dust control procedures during excavations) and sound health physics and industrial hygiene procedures in accordance with DOE's ALARA process (e.g., effective monitoring, personal protective equipment, and good housekeeping procedures).

Contaminated material would be stored on-site in engineered facilities to ensure that radiological exposure to SLDS employees would not exceed DOE's limit for the general public (i.e., $100 \mathrm{mrem} / \mathrm{yr}$ ). Chemical exposure to stored material would not be significant because dust would not be resuspended and dermal contact would not occur while the piles are covered and maintained.

\subsection{POTENTIAL ENVIRONMENTAL IMPACTS}

Potential environmental impacts of this removal action would be minimal because all actions would be conducted within the currently active SLDS, which has already been completely developed. Most of the SLDS property is currently covered with buildings, concrete, or asphalt. If the proposed removal action (Alternative 3 ) is implemented, the potential for leaching of contaminants to groundwater would decrease because some of the contaminated soil would be excavated and placed on an impermeable surface that would prevent leaching. Although impacts to groundwater or nearby surface water could potentially occur as a result of 
site activities, the potential for such impacts would be minimized by good engineering practices during the removal action (e.g., sediment barriers to minimize the amount of sediment leaving the work area and containment of surface runoff during storms).

The removal action might also result in temporary air impacts due to resuspension of dust during decontamination or excavation activities. Again, practices to reduce dust generation would be employed (e.g., wetting and/or covering exposed surfaces) during the action period. These impacts would be eliminated after the removal action is completed. 


\section{REFERENCES}

Agency for Toxic Substances and Disease Registry, 1990, Toxicological Profile for Lead, ATSDR/TP88/17, prepared by Syracuse Research Corporation for U.S. Public Health Service in collaboration with U.S. Environmental Protection Agency, June.

Bechtel National, Inc., 1990a, Chemical Characterization Report for the St. Louis Airport Site and Latty Avenue Properties, St. Louis, Missouri, DOE/OR/20722-206, prepared for U.S. Department of Energy, Oak Ridge Operations, Oak Ridge, Tẹnn., July.

Bechtel National, Inc., 1990b, Radiological, Chemical, and Hydrogeological Characterization Report for the St. Louis Downtown Site in St. Louis, Missouri, DOE/OR/20722-258, prepared for U.S. Department of Energy, Oak Ridge Operations, Oak Ridge, Tenn., April.

Bechtel National, Inc., 1990c, Work Plan for the Remedial Investigation/Feasibility Study-Environmental Impact Statement for the St. Louis Site in St. Louis, Missouri (Draft), DOE/OR/20722-271.1, prepared for U.S. Department of Energy, Oak Ridge Operations, Oak Ridge, Tenn., July.

Dreesen, D.R., et al., 1982, Mobility and Bioavailability of Uranium Mill Tailings Contaminants, Environmental Science and Technology, 16:702-709.

Federal Insurance Administration, 1979, Flood Insurance Rate Map, City of St. Louis, Independent City, Panel 10 of 40, Community Panel No. 290385 0010A, U.S. Department of Housing and Urban Development, July 16.

Gilbert, T.L., et al., 1989, A Manual for Implementing Residual Radioactive Material Guidelines, ANL/ES-160, DOE/CH/8901, prepared by Argonne National Laboratory for U.S. Department of Energy, June.

International Commission on Radiological Protection, 1975, Report of the Task Group on Reference Man, ICRP Publication 23, Pergamon Press, Oxford, United Kingdom.

International Commission on Radiological Protection, 1981, Limits for Inhalation of Radon Daughters by Workers, ICRP Publication 32, Pergamon Press, Oxford, United Kingdom.

Liedle, S.D., 1990, Input for St. Louis Baseline Risk Assessment Study, letter from S.D. Liedle (Bechtel National, Inc., Oak Ridge, Tenn.) to M. Picel (Argonne National Laboratory, Argonne, Ill.), May 29.

National Council on Radiation Protection and Measurements, 1987, Exposure of the Population in the United States and Canada from Natural Background Radiation, NCRP Report No. 94, Bethesda, Md., Dec. 30.

National Research Council, 1988, Health Risks of Radon and Other Internally Deposited Alpha Emitters, BEIR IV Report, report of the Committee on the Biological Effects of Ionizing Radiation, Washington, D.C. 
Occupational Safety and Health Administration, 1989, Air Contaminants - Permissible Exposure Limits (Title 29 CFR Part 1910.1000), U.S. Department of Labor, U.S. Government Printing Office, Washington, D.C.

Stokinger, H.E., 1981, The Metals, in Patty's Industrial Hygiene and Toxicology, 3rd rev. Ed., Vol. 1, G.D. Clayton and F.E. Clayton, eds., John Wiley \& Sons, New York.

U.S. Department of Energy, 1988, Radiation Protection for Occupational Workers, DOE Order 5480.11 .

U.S. Department of Energy, 1990, Radiation Protection of the Public and the Environment, DOE Order 5400.5.

U.S. Environmental Protection Agency, 1989, Background Information Document, Environmental Impact Statement for NESHAPS Radionuclides, Volume 2, Risk Assessment Methodology, EPA/520/189/005, Office of Radiation Programs, Washington, D.C., Sept. 
APPENDIX A:

REGULATORY REQUIREMENTS POTENTIALLY APPLICABLE OR RELEVANT AND APPROPRIATE TO THE PROPOSED ACTION 


\section{NOTATION}

The following is a list of acronyms, initialisms, and abbreviations (including units of measure) used in this appendix.

\section{Acronyms, Initialisms, and Abbreviations}

$\begin{array}{ll}\text { ARAR } & \text { applicable or relevant and appropriate requirement } \\ \text { CERCLA } & \text { Comprehensive Environmental Response, Compensation, and Liability Act } \\ \text { CFR } & \text { Code of Federal Regulations } \\ \text { CSR } & \text { Code of State Regulations } \\ \text { DOE } & \text { U.S. Department of Energy } \\ \text { EPA } & \text { U.S. Environmental Protection Agency } \\ \text { HEPA } & \text { high-efficiency-particulate air } \\ \text { NPDES } & \text { National Pollutant Discharge Elimination System } \\ \text { PL } & \text { public law } \\ \text { RSMo. } & \text { Reoised Statutes of Missouri } \\ \text { SLDS } & \text { St. Louis Downtown Site } \\ \text { Stat. } & \text { statute } \\ \text { TBC } & \text { to-be-considered (requirements) } \\ \text { TCLP } & \text { toxic characteristic leaching procedure } \\ \text { USC } & \text { U.S. Code }\end{array}$

\section{Units of Measure}

$\begin{array}{ll}\mathrm{cm} & \text { centimeter(s) } \\ \mathrm{cm}^{2} & \text { square centimeter(s) } \\ \mathrm{cm}^{3} & \text { cubic centimeter(s) } \\ \mathrm{dBa} & \text { adjusted decibel(s) } \\ \mathrm{dpm} & \text { disintegration(s) per minute } \\ \mathrm{ft}^{3} & \text { cubic foot (feet) } \\ \mathrm{g} & \text { gram(s) } \\ \mathrm{h} & \text { hour(s) } \\ \mathrm{L} & \text { liter(s) } \\ \mathrm{lb} & \text { pound(s) } \\ \mu \mathrm{Ci} & \text { microcurie(s) } \\ \mu \mathrm{g} & \text { microgram(s) } \\ \mu \mathrm{m} & \text { micrometer(s) } \\ \mu \mathrm{R} & \text { microroentgen(s) } \\ \mathrm{m} & \text { square meter(s) } \\ \mathrm{m} & \text { cubic meter(s) } \\ \mathrm{mg} & \text { milligram (s) } \\ \mathrm{mL} & \text { milliliter(s) } \\ \mathrm{mrad} & \text { millirad(s) } \\ \mathrm{mrem} & \text { millirem(s) } \\ \mathrm{MeV} & \text { million electron volts }\end{array}$




$\begin{array}{ll}\mathrm{pCi} & \text { picocurie(s) } \\ \mathrm{s} & \text { second(s) } \\ \mathrm{WL} & \text { working level } \\ \mathrm{yr} & \text { year(s) }\end{array}$




\section{APPENDIX A:}

\section{REGULATORY REQUIREMENTS POTENTIALLY APPLICABLE OR RELEVANT AND APPROPRIATE TO THE PROPOSED ACTION}

Potential requirements for a proposed action can be grouped into two general categories: (1) applicable or relevant and appropriate requirements (ARARs) and (2) "to-be-considered" (TBC) requirements. The first category consists of promulgated standards (e.g., public laws codified at the state or federal level) that may be applicable or relevant and appropriate to all or part of the proposed action. The second category consists of standards or guidelines that have been published but not promulgated and that may have specific bearing on all or part of the action, for example, U.S. Department of Energy (DOE) Orders.

In addressing a requirement that may affect the proposed action, a determination is made regarding its relationship to (1) the location of the action, (2) the contaminants involved, and (3) the specific components of the action, for example, factors associated with a certain technology. Any regulation, standard, requirement, criterion, or limitation under any federal or state environmental law or state facility siting law may be either applicable or relevant and appropriate to a response action, but not both. Only those state laws may become ARARs that are (1) promulgated, such that they are legally enforceable and generally applicable (i.e., consistently applied) and (2) more stringent than federal laws.

Applicable requirements are those that specifically address the circumstance(s) at the site, whereas relevant and appropriate requirements are those that address circumstances sufficiently similar that they are well suited to the site. That is, a potential ARAR is applicable if its prerequisites or regulated conditions are specifically met by the conditions of the proposed action (e.g., site location in a floodplain); if the conditions of a requirement are not specifically applicable, then a determination must be made as to whether they are sufficiently similar to be considered both relevant and appropriate (e.g., in terms of contaminant similarities and the nature and setting of the proposed action). This similarity is determined on the basis of best professional judgment, considering factors that include (1) the purpose of the requirement; (2) the medium, substance, action, type of place, and type and size of facility regulated; and (3) the use or potential use of affected resources, relative to the nature of these factors at the site.

In accordance with U.S. Environmental Protection Agency (EPA) guidance on ARARs, only applicable requirements are evaluated for off-site actions, whereas both applicable and relevant and appropriate requirements are evaluated for on-site actions. On-site actions must comply. with a requirement that is determined to be relevant and appropriate to the same extent as one that is determined to be applicable. However, a determination of relevance and appropriateness may be applied to only portions of a requirement whereas a determination of applicability is applied to the requirement as a whole. On-site actions, such as the proposed removal action, must comply with substantive requirements of ARARs but not related administrative and procedural requirements. 'For example, response actions conducted on-site would not require a permit but would be conducted in accordance with the permitted conditions.

Potential TBC requirements, such as concentration limits proposed in interim EPA guidance memoranda, are typically considered only if no promulgated requirements exist that are either applicable or relevant and appropriate. Thus, TBC requirements are often considered 
secondary to ARARs. However, certain TBC requirements such as DOE Orders are developed on the basis of promulgated standards and can necessitate the same degree of compliance as ARARs. Because the removal action at the St. Louis Downtown Site (SLDS) is being proposed by DOE, it would be conducted in accordance with DOE Orders irrespective of the "TBC" designation of these Orders under the formal ARAR process.

Activities at the SLDS will also be conducted in compliance with worker protection requirements, including those identified in the Occupational Safety and Health Act and in a number of specific DOE Orders. Because these requirements address employee protection rather than environmental protection, they are not subject to consideration for attainment or waiver under the ARAR evaluation process. Rather, they are requirements with which the response actions must comply. Certain of these requirements are listed in this appendix for informational purposes (i.e., to identify worker-protection requirements that will be met by the proposed action) rather than as andication of a formal ARAR evaluation.

Potential location-specific, contaminant-specific, and action-specific ARARs and TBC requirements for the proposed action are identified and evaluated in Tables A.1, A.2, and A.3, respectively. The preliminary ARAR and TBC determinations for the listed requirements are also indicated in the tables. Because this appendix presents a comprehensive list of requirements with considerable overlap of regulated conditions, all determinations have been identified as "potentially" applicable, relevant and appropriate, or to be considered. These determinations will be finalized in consultation with the state of Missouri and EPA Region VII prior to implementing the proposed action. During finalization, the requirements identified as potentially applicable will be reviewed to confirm direct applicability; only one requirement will be finalized from among those that regulate the same conditions. For those identified as potentially relevant and appropriate and as TBC requirements, both the specific portion(s) of the requirements that have bearing on the proposed action and the manner in which compliance would be achieved will be finalized. After the finalization process, certain of the requirements will remain potentially an ARAR or a TBC requirement as the action proceeds, pending identification of the existence of their prerequisites or regulated conditions (e.g., the presence of cultural resources or threatened or endangered species in the affected area). Because the scope of the proposed action does not include waste disposal, potential ARARs associated with disposal of radioactive, chemically hazardous, or uncontaminated material are not included in Table A.3.

In accordance with the Comprehensive Environmental Response, Compensation, and Liability Act (CERCLA), as amended, and the National Oil and Hazardous Substance Pollution Contingency Plan, an alternative that does not meet an ARAR may be selected if one of the following waiver conditions is met:

- The alternative is an interim measure and will become part of a total remedial action that will attain the requirement;

- Compliance with the requirement will result in greater risk to human health and the environment than other alternatives;

- Compliance with the requirement is technically impracticable from an engineering perspective;

- The alternative will attain a standard of performance that is equivalent to that required under the otherwise applicable ARAR through use of another method or approach; 
- For state requirements, the state has not consistently applied the promulgated requirement (or demonstrated the intention to do so) in similar circumstances at other remedial actions within the state; or

- For Superfund-financed actions only, an alternative that attains the ARAR will not provide a balance between achieving protectiveness at the site and retaining sufficient funds for responses at other sites. (This condition is not relevant to the SLDS because Superfund money is not being used to finance the cleanup.)

The first waiver condition applies directly to the proposed removal action because it is only part of the overall remedial action for the project. 


\section{TABLE A.1 Potential Location-Specific Requirements}

\begin{tabular}{|c|c|c|c|c|}
\hline Potential ARAR & Location & Requirement & $\begin{array}{l}\text { Preliminary } \\
\text { Determination }\end{array}$ & Remarks \\
\hline $\begin{array}{l}\text { Antiquity Act; Historic Sites Act } \\
\text { (16 USC 431-433; } 16 \text { USC 461-467; } \\
\text { 40 CFR 6.301(a)) }\end{array}$ & Land & $\begin{array}{l}\text { Cultural resources, such as historic buildings and } \\
\text { sites and natural landmarks, shall be preserved } \\
\text { on federal land to avoid adverse impacts. }\end{array}$ & $\begin{array}{l}\text { Potentially } \\
\text { applicable }\end{array}$ & $\begin{array}{l}\text { No adverse impacts to such resources are } \\
\text { expected to result from the proposed action; } \\
\text { however, if these resources were affected, the } \\
\text { requirement would be applicable. }\end{array}$ \\
\hline $\begin{array}{l}\text { National Historic Preservation Act, } \\
\text { as amended (16 USC } 470 \text { et seq.; } 40 \\
\text { CFR } 6.301 \text { (b); } 36 \text { CFR } 800 \text { ) }\end{array}$ & Land & $\begin{array}{l}\text { The effect of any federally assisted undertaking } \\
\text { shall be taken into account for any district, site, } \\
\text { building, structure, or object included in or } \\
\text { eligible for the National Register of Historic Places. }\end{array}$ & $\begin{array}{l}\text { Potentially } \\
\text { applicable }\end{array}$ & $\begin{array}{l}\text { No adverse impacts to such properties are } \\
\text { expected to result from the proposed action; } \\
\text { however, if these resources were affected, the } \\
\text { requirement would be applicable. }\end{array}$ \\
\hline $\begin{array}{l}\text { Archeological and Historic Preserva- } \\
\text { tion Act (16 USC 469; } 40 \text { CFR } \\
\text { 6.301(c); PL 93-291; } 88 \text { Stat. 174) }\end{array}$ & Land & $\begin{array}{l}\text { Prehistorical, historical, and archeological data } \\
\text { that might be destroyed as a result of a federal, } \\
\text { federally assisted, or federally licensed activity or } \\
\text { program shall be preserved. }\end{array}$ & $\begin{array}{l}\text { Potentially } \\
\text { applicable }\end{array}$ & $\begin{array}{l}\text { No destruction of such data is expected to result } \\
\text { from the proposed action. The SLDS is in an } \\
\text { area that has been considerably disturbed by } \\
\text { past human activities; therefore, this area is not } \\
\text { expected to contain any such data. However, if } \\
\text { these data were affected, the requirement would } \\
\text { be applicable. }\end{array}$ \\
\hline $\begin{array}{l}\text { Archeological Resources Protection } \\
\text { Act (16 USC } 470(a) \text { ) }\end{array}$ & Land & $\begin{array}{l}\text { A permit must be obtained if an action on public } \\
\text { or Indian lands could impact archeological } \\
\text { resources. }\end{array}$ & $\begin{array}{l}\text { Potentially } \\
\text { applicable }\end{array}$ & $\begin{array}{l}\text { No impacts to archeological resources are } \\
\text { expected to result from the proposed action. } \\
\text { The SLDS is in an area that has been } \\
\text { considerably disturbed by past human activities; } \\
\text { therefore, this area is not expected to contain } \\
\text { any such resources. However, if these resources } \\
\text { were affected, the requirement would be } \\
\text { applicable. }\end{array}$ \\
\hline $\begin{array}{l}\text { Protection and Enhancement of the } \\
\text { Cultural Environment (Executive } \\
\text { Order 11593; } 40 \text { CFR 6.301) }\end{array}$ & Land & $\begin{array}{l}\text { Historic, architectural, archeological, and cultural } \\
\text { resources shall be preserved, restored, and } \\
\text { maintained, and shall be evaluated for inclusion } \\
\text { in the National Register. }\end{array}$ & $\begin{array}{l}\text { Potentially } \\
\text { applicable }\end{array}$ & $\begin{array}{l}\text { No impacts to such resources are expected to } \\
\text { result from the proposed action. The SLDS is in } \\
\text { an area that has been considerably disturbed by } \\
\text { past human activities; therefore, this area is not } \\
\text { expected to contain any such resources. How- } \\
\text { ever, if these resources were affected, the } \\
\text { requirement would be applicable. }\end{array}$ \\
\hline $\begin{array}{l}\text { Endangered Species Act, as } \\
\text { amended (16 USC 1531-1543; } 50 \text { CFR } \\
17.402 ; 40 \text { CFR } 6.302(\mathrm{~h}) \text { ) }\end{array}$ & Any & $\begin{array}{l}\text { Federal agencies shall ensure that any action } \\
\text { authorized, funded, or carried out by the agency } \\
\text { is not likely to jeopardize the continued existence } \\
\text { of any threatened or endangered species or } \\
\text { destroy or adversely modify any critical liabitat. }\end{array}$ & $\begin{array}{l}\text { Potentially } \\
\text { applicable }\end{array}$ & $\begin{array}{l}\text { No critical habitat exists in the affected area, and } \\
\text { no adverse impacts to threatened or endangered } \\
\text { species are expected to result from the proposed } \\
\text { action; however, if such species were affected, } \\
\text { the requirement would be applicable. }\end{array}$ \\
\hline
\end{tabular}


TABLE A.1 (Cont'd)

\begin{tabular}{cccc}
\hline & Preliminary & Determination \\
Potential ARAR & Location & Requirement & Remarks \\
\hline
\end{tabular}

Missouri Wildlife Code (1989)

(RSMo. 252.240; 3 CSR 10-4.111),

Endangered Species

Missouri Wildlife Code (1989)

(ISSMo. 252.240; 3 CSR 10-4.110)

General Prohibition; Applications

Missouri Wildlife Code (1989)

(RSMo. 252.240; 3 CSR 10-4.115),

Special Management Areas

Missouri Wildlife Code (1978)

(RSMo. 252.040), Taking of

Wildlife -- Rules and Regulations

Missouri Wildlife Code (1978)

(RSMo. 252.240), Endangered species

importation, transportation, or sale,

when prohibited -- how designated

-- penalty

Missouri Wildlife Code (1978)

(RSMo. 252.210), Contamilution of

streams
Any Endangered species, i.e., those designated by the Missouri Department of Conservation and the

U.S. Department of the Interior as threatened or endangered (see 1978 Code, RSMo. 252.240) may not be pursued, taken, possessed, or killed.

Wildlife, including their homes and eggs, may not be taken or molested.

Wildlife shall not be taken, pursued, or molested on any state or federal wildlife refuge or any wild life manngement area, except under permitted conditions.

Wildlife shall not be taken or pursued, except under permitted conditions.

The Missouri Department of Conservation shall file with the state a list of animal species designated as endangered (for subsequent consideration of related requirements).

It is unlawful to put any deleterious substances into waters of the state in quantities sulficient to injure fish, except under precautionary measures approved by the commission.
Potentially applicable

No critical habitat exists in the affected area, and no adverse impacts to threatened or endangered species are expected to result from the proposed action. However, if such species were affected, the requirement would be applicable.

Potentially relevant and appropriate

Potentially relevant and appropriate

Potentially relevant and appropriate

Potentially applicable

Potentially applicable
No wildlife would be actively taken or molested as part of the proposed action. Mitigative measures would be taken to minimize potential environmental impacts; these would serve to minimize impacts to wildlife.

Not applicable because the SLIDS is not a wildlife refuge or management area. No wildlife would be actively taken, pursued, or molested in any wildlife areas as part of the proposed action. Mitigative measures would be taken to minimize potential environnental impacts; these would serve to minimize inpacts to wildlife.

No wildlife would be actively taken or pursued as part of the proposed action. Mitigative measures would be taken to minimize potential environmental impacts; these would serve to minimize impacts to wildlife.

No critical habitat exists in the affected area, and no adverse impacts to threatened or endangered species are expected to result from the proposed action. However, if such species were affected, the requirement would be applicable.

It is not anticipated that quantities of deleterious substances sufficient to injure fish would be discharged to any waters of the state. 
TABLE A.1 (Cont'd)

\begin{tabular}{|c|c|c|c|c|}
\hline Potential ARAR & Location & Requirement & $\begin{array}{l}\text { Preliminary - } \\
\text { Determination }\end{array}$ & Remarks \\
\hline $\begin{array}{l}\text { Fish and Wildlife Coordination Act } \\
\text { (14 USC 441-444; } 40 \text { CFR 4.302(a)) }\end{array}$ & Any & $\begin{array}{l}\text { Adequate protection of fish and wildlife } \\
\text { resources is required when any federal } \\
\text { department or agency proposes or authorizes } \\
\text { any modification (e.g., diversion or channeling) } \\
\text { of any stream or other water body or any } \\
\text { modification of areas affecting any stream or } \\
\text { other water body. }\end{array}$ & $\begin{array}{l}\text { Potentially } \\
\text { applicable }\end{array}$ & $\begin{array}{l}\text { No modification of streams or stream areas is } \\
\text { planned as part of the proposed action. If such } \\
\text { modification occurred, the pertinent } \\
\text { requirements of this act would be followed } \\
\text { during implementation of the proposed action. }\end{array}$ \\
\hline $\begin{array}{l}\text { Floodplain Management (Executive } \\
\text { Order 11988; } 40 \text { CFR 1022) }\end{array}$ & Floodplain & $\begin{array}{l}\text { Federal agencies shall avoid, to the maximum } \\
\text { extent possible, any adverse impacts associated } \\
\text { with direct and indirect development of a } \\
\text { floodplain. }\end{array}$ & Not an ARAR & $\begin{array}{l}\text { No floodplain is located in the area affected by } \\
\text { the proposed action. }\end{array}$ \\
\hline Governor's Executive Order 82-19 & Floodplain & $\begin{array}{l}\text { Potential effects of actions taken in a floodplain } \\
\text { must be evaluated to avoid adverse impacts. }\end{array}$ & Not an ARAR & $\begin{array}{l}\text { No floodplain is located in the area affected by } \\
\text { the proposed action. }\end{array}$ \\
\hline $\begin{array}{l}\text { Protection of Wetlands (Executive } \\
\text { Order 11990; } 40 \text { CFR 1022) }\end{array}$ & Wetland & $\begin{array}{l}\text { Federal agencies shall avoid, to the extent } \\
\text { possible, any adverse impacts associated with } \\
\text { the destruction or loss of wetlands and the } \\
\text { support of new construction in wetlands if a } \\
\text { practicable alternative exists. }\end{array}$ & Not an ARAR & $\begin{array}{l}\text { No wetland is located in the area affected by the } \\
\text { proposed action. }\end{array}$ \\
\hline
\end{tabular}




\section{TABLE A.2 Potential Contaminant-Specific Requirements}

\begin{tabular}{|c|c|c|c|c|c|}
\hline Potential ARAR & Contaminant & Medium & Requirement & Determination & Remarks \\
\hline $\begin{array}{l}\text { Federal Water Pollution } \\
\text { Control Act, Clean Water } \\
\text { Act ( } 33 \text { USC 1251-1376; } \\
\text { Water Quality Standards (40 } \\
\text { CFR 131), National } \\
\text { Pollutant Discliarge } \\
\text { Elimination System (40 CFR } \\
\text { 122-125) }\end{array}$ & Any & Water & $\begin{array}{l}\text { Permitting authority for surface water discharges is } \\
\text { delegated to the states for the National Pollutant } \\
\text { Discharge Elimination System (NPDES) process. }\end{array}$ & $\begin{array}{l}\text { Potentially } \\
\text { applicable }\end{array}$ & $\begin{array}{l}\text { Wastewater resulting from } \\
\text { the proposed action (e.g., } \\
\text { wash water) would be } \\
\text { managed in accordance with } \\
\text { the NPDES process as part of } \\
\text { the agreement currently in } \\
\text { place for the SLDS (owners), } \\
\text { which addresses permitted } \\
\text { discharges. }\end{array}$ \\
\hline $\begin{array}{l}\text { Health and Environmental } \\
\text { Protection Standards for } \\
\text { Uranium and Thorium Mill } \\
\text { Tailings (40 CFR 192) }\end{array}$ & Radium & Soil & $\begin{array}{l}\text { The concentration of radium in soil averaged over an } \\
\text { area of } 100 \mathrm{~m}^{2} \text { shall not exceed the background level } \\
\text { by more than } 5 \mathrm{pCi} / \mathrm{g} \text { in the top } 15 \mathrm{~cm} \text { of soil or } \\
15 \mathrm{pCi} / \mathrm{g} \text { in each } 15-\mathrm{cm} \text { layer below the top layer. }\end{array}$ & $\begin{array}{l}\text { Potentially } \\
\text { relevant and } \\
\text { appropriate }\end{array}$ & $\begin{array}{l}\text { The SI.DS is not a mill } \\
\text { tailings site, so these } \\
\text { requirements are not appli- } \\
\text { cable. However, they may } \\
\text { be considered relevant and } \\
\text { appropriate because of con- } \\
\text { taminant similarity. }\end{array}$ \\
\hline $\begin{array}{l}\text { Radiation Protection of the } \\
\text { Public and the Environment } \\
\text { (DOE Order 5400.5) }\end{array}$ & $\begin{array}{l}\text { Radium and } \\
\text { thorium }\end{array}$ & Soil & $\begin{array}{l}\text { Concentrations of radium-226, radium-228, } \\
\text { thorium-230, and throium-232 averaged over an area } \\
\text { of } 100 \mathrm{~m}^{2} \text { are } 5 \mathrm{pCi} / \mathrm{g} \text { in the top } 15 \mathrm{~cm} \text { of soil and } \\
15 \mathrm{pCi} / \mathrm{g} \text { in each } 15-\mathrm{cm} \text { layer below the top layer. } \\
\text { These guidelines take into account ingrowth of } \\
\text { radium-226 from thorium- } 230 \text { and of radium- } 228 \text { from }\end{array}$ & To be considered & $\begin{array}{l}\text { Although not promulgated } \\
\text { standards, these constitute } \\
\text { requirements for protection } \\
\text { of the public with which the } \\
\text { proposed action will comply. }\end{array}$ \\
\hline
\end{tabular}

26 from thorium-230 and of radium-228 from

thorium-230 and radium-226 or both thorium-232 and radium-228 are present and not in secular equilibrium the appropriate guideline is applied as a limit for the radionuclide with the higher concentration. 
TABLE A.2 (Cont'd)

\begin{tabular}{|c|c|c|c|c|c|}
\hline Potential ARAR & Contaminant & Medium & Requirement & Determination & Remarks \\
\hline $\begin{array}{l}\text { Missouri Radiation } \\
\text { Regulations; Protection } \\
\text { Against Ionizing Radiation } \\
\text { (19 CSR 20-10.040), } \\
\text { Maximum Permissible } \\
\text { Exposure Limits }\end{array}$ & Radiation & Air & $\begin{array}{l}\text { For persons outside a controlled area, the maximum } \\
\text { permissible whole-body dose due to sources in or } \\
\text { migrating from the controlled area is limited to } 2 \text { mrem } \\
\text { in any } 1 \text { hour, } 0.1 \text { rem in any } 7 \text { consecutive days, and } \\
0.5 \text { rem in any year. (Note: a controlled area is an area } \\
\text { that requires control of access, occupancy, and working } \\
\text { conditions for radiation protection purposes; } 0.5 \text { rem = } \\
500 \text { mrem.) }\end{array}$ & $\begin{array}{l}\text { Potentially } \\
\text { applicable }\end{array}$ & $\begin{array}{l}\text { These requirements may be } \\
\text { applicable to protection of } \\
\text { the public during } \\
\text { implementation of the } \\
\text { proposed action. }\end{array}$ \\
\hline $\begin{array}{l}\text { Radiation Protection of the } \\
\text { Public and the Environment } \\
\text { (DOE Order 5400.5) }\end{array}$ & Radiation & Air & $\begin{array}{l}\text { The basic dose limit for nonoccupationally exposed } \\
\text { individuals is } 100 \mathrm{mrem} / \mathrm{yr} \text { above background, } \\
\text { committed effective dose equivalent. Further, all } \\
\text { radiation exposures must be reduced to levels as low as } \\
\text { reasonably achievable. }\end{array}$ & $\begin{array}{l}\text { To be } \\
\text { considered }\end{array}$ & $\begin{array}{l}\text { Although not promulgated } \\
\text { standards, these require- } \\
\text { ments are derived from such } \\
\text { standards and they constitute } \\
\text { requirements for protection } \\
\text { of the public with which the } \\
\text { proposed action will comply. }\end{array}$ \\
\hline $\begin{array}{l}\text { Health and Environmental } \\
\text { Protection Standards for } \\
\text { Uranium and Thorium Mill } \\
\text { Tailings ( } 40 \text { CFR 192) }\end{array}$ & Radiation & Any & $\begin{array}{l}\text { Processing operations during and prior to the end of } \\
\text { the closure period at a facility managing uranium by- } \\
\text { product material should be conducted in a manner that } \\
\text { provides reasonable assurance that the annual dose } \\
\text { equivalent does not exceed } 25 \text { mrem to the whole body, } \\
75 \text { mrem to the thyroid, and } 25 \text { mrem to any other } \\
\text { organ of any member of the public as a result of } \\
\text { exposures to the planned discharge of radioactive } \\
\text { material to the general environment (excluding } \\
\text { radon- } 222 \text { and its decay products). }\end{array}$ & $\begin{array}{l}\text { Potentially } \\
\text { relevant and } \\
\text { appropriate }\end{array}$ & $\begin{array}{l}\text { These requirements are not } \\
\text { applicable because the pro- } \\
\text { posed action does not con- } \\
\text { stitute a processing opera- } \\
\text { tion, nor does it include a } \\
\text { planned discharge of radio- } \\
\text { active material to the } \\
\text { environment. However, } \\
\text { these requirements may be } \\
\text { considered relevant and } \\
\text { appropriate to protection of } \\
\text { the public during imple- } \\
\text { mentation of the proposed } \\
\text { action. }\end{array}$ \\
\hline
\end{tabular}


TABLE A.2 (Cont'd)

\begin{tabular}{|c|c|c|c|c|c|}
\hline Potential ARAR & Contaminant & Medium & Requirement & Determination & Remarks \\
\hline $\begin{array}{l}\text { National Emission } \\
\text { Standards for Hazardous } \\
\text { Air Pollutants (40 CFR 61), } \\
\text { Subpart H, National } \\
\text { Enission Standards for } \\
\text { Emissions of Radionuclides } \\
\text { Other than Radon from U.S. } \\
\text { Department of Energy } \\
\text { (DOE) lacilities }\end{array}$ & $\begin{array}{l}\text { Radionuclides } \\
\text { other than } \\
\text { radon- } 220 \text { and } \\
\text { radon- } 222\end{array}$ & Air & $\begin{array}{l}\text { Emissions of radionuclides other than radon- } 220 \text { and } \\
\text { radon-222 to the ambient air from DOE facilities shall } \\
\text { not exceed those amounts that would cause any } \\
\text { member of the public in any year an effective dose } \\
\text { equivalent of } 10 \mathrm{mrem} / \mathrm{yr} \text {. }\end{array}$ & $\begin{array}{l}\text { Potentially } \\
\text { relevant and } \\
\text { appropriate }\end{array}$ & $\begin{array}{l}\text { These requirements are not } \\
\text { strictly applicable because } \\
\text { the SLDS is not a DOE } \\
\text { facility. These requirements } \\
\text { may be considered relevant } \\
\text { and appropriate because the } \\
\text { site was previously operated } \\
\text { under contract for DOE's } \\
\text { predecessor agency such that } \\
\text { conditions similar to the pre- } \\
\text { requisite conditions are } \\
\text { present. }\end{array}$ \\
\hline \multirow[t]{2}{*}{$\begin{array}{l}\text { Health and Environmental } \\
\text { Protection Standards for } \\
\text { Uranium and Thorium Mill } \\
\text { Tailings ( } 40 \mathrm{CFR} \text { 192) }\end{array}$} & Radon & Air & $\begin{array}{l}\text { Releases of radon from tailings disposal piles shall not } \\
\text { exceed an average rate of } 20 \mathrm{pCi} / \mathrm{m}^{2}-\mathrm{s} \text { or increase the } \\
\text { annual average concentration in air outside the disposal } \\
\text { site by more than } 0.5 \mathrm{pCi} / \mathrm{L} \text {. } \\
\text { - }\end{array}$ & $\begin{array}{l}\text { Potentially } \\
\text { relevant and } \\
\text { appropriate }\end{array}$ & $\begin{array}{l}\text { The SI.DS is not a mill } \\
\text { tailings site and disposal is } \\
\text { beyond the scope of the } \\
\text { proposed action, so these } \\
\text { requirements nre not appli- } \\
\text { cable. However, they may } \\
\text { be considered relevant and } \\
\text { appropriate, e.g., for an } \\
\text { outdoor storage facility, } \\
\text { because of contaminant } \\
\text { similarity. }\end{array}$ \\
\hline & $\begin{array}{l}\text { Radon decay } \\
\text { prod ucts }\end{array}$ & Air & $\begin{array}{l}\text { The annual average (or equivalent) radon decay } \\
\text { product concentration, including background, in any } \\
\text { habitable building shall not exceed } 0.02 \text { working level } \\
\text { (WL.) or a maximum of } 0.03 \mathrm{WL}-- \text { where a WL. is any } \\
\text { combination of short-lived radon decay products in } 1 \\
\text { liter of air, without regard to the degree of equilibrium } \\
\text { that will result in the emission of } 1.3 \times 10^{5} \mathrm{MeV} \text { of } \\
\text { alpha energy. (lior radon- } 222 \mathrm{in} \text { equilibrium with its } \\
\text { decay products, } 1 \mathrm{WL}=100 \mathrm{pCi} / \mathrm{L} \text {.) }\end{array}$ & $\begin{array}{l}\text { Potentially } \\
\text { relevant and } \\
\text { appropriate }\end{array}$ & $\begin{array}{l}\text { The SI.DS is not a mill } \\
\text { tailings site, so these } \\
\text { requirements are not appli- } \\
\text { cable. However, they may } \\
\text { be considered relevant and } \\
\text { appropriate because, } \\
\text { although the buildings are } \\
\text { not habitable, they could be } \\
\text { occupied by workers on a } \\
\text { routine basis. }\end{array}$ \\
\hline
\end{tabular}


TABLE A.2 (Cont'd)

\begin{tabular}{|c|c|c|c|c|c|}
\hline Potential ARAR & Contaminant & Medium & Requirement & Determination & Remarks \\
\hline \multirow[t]{2}{*}{$\begin{array}{l}\text { Radiation Protection of the } \\
\text { Public and the Environment } \\
\text { (DOE Order 5400.5) }\end{array}$} & Radon-222 & Air & $\begin{array}{l}\text { The above-background concentration of radon- } 222 \text { in } \\
\text { air above an interim storage facility must not exceed } \\
100 \mathrm{pCi} / \mathrm{L} \text { at any point, an annual average of } 30 \mathrm{pCi} / \mathrm{L} \\
\text { over the facility, or an annual average of } 3 \mathrm{pCi} / \mathrm{L} \text { at or } \\
\text { above any location outside the site. (See also the } \\
\text { discussion for DOE Order } 5820.2 \mathrm{~A} \text { in Table } \mathrm{A} .3 \text { ) }\end{array}$ & To be considered & $\begin{array}{l}\text { Although not promulgated } \\
\text { standards, these constitute } \\
\text { requirements for protection } \\
\text { of the public with which the } \\
\text { proposed action will comply. }\end{array}$ \\
\hline & $\begin{array}{l}\text { Radon-220 and } \\
\text { radon-222 }\end{array}$ & Air & $\begin{array}{l}\text { The immersion-derived concentration guide for both } \\
\text { radon- } 220 \text { and radon- } 222 \text { in air in an uncontrolled area } \\
\text { is } 3 \mathrm{pCi} / \mathrm{L} \text {. }\end{array}$ & To be considered & $\begin{array}{l}\text { Although not promulgated } \\
\text { standards, these constitute } \\
\text { requirements for protection } \\
\text { of the public with which the } \\
\text { proposed action will comply. }\end{array}$ \\
\hline $\begin{array}{l}\text { Health and Environmental } \\
\text { Protection Standards for } \\
\text { Uranium and Thorium Mill } \\
\text { Tailings ( } 40 \text { CFR 192) }\end{array}$ & $\begin{array}{l}\text { External gamma } \\
\text { radiation }\end{array}$ & Air & $\begin{array}{l}\text { The level of external gamma radiation in any occupied } \\
\text { or habitable building must not exceed the background } \\
\text { level by more than } 20 \mu \mathrm{R} / \mathrm{h} \text {. }\end{array}$ & $\begin{array}{l}\text { Potentially } \\
\text { relevant and } \\
\text { appropriate }\end{array}$ & $\begin{array}{l}\text { The SLDS is not a mill } \\
\text { tailings site, so these } \\
\text { requirements are not appli- } \\
\text { cable. However, they may } \\
\text { be considered relevant and } \\
\text { appropriate if a building } \\
\text { could be occupied by } \\
\text { workers on a routine basis. }\end{array}$ \\
\hline
\end{tabular}


TABLE A.2 (Cont'd)

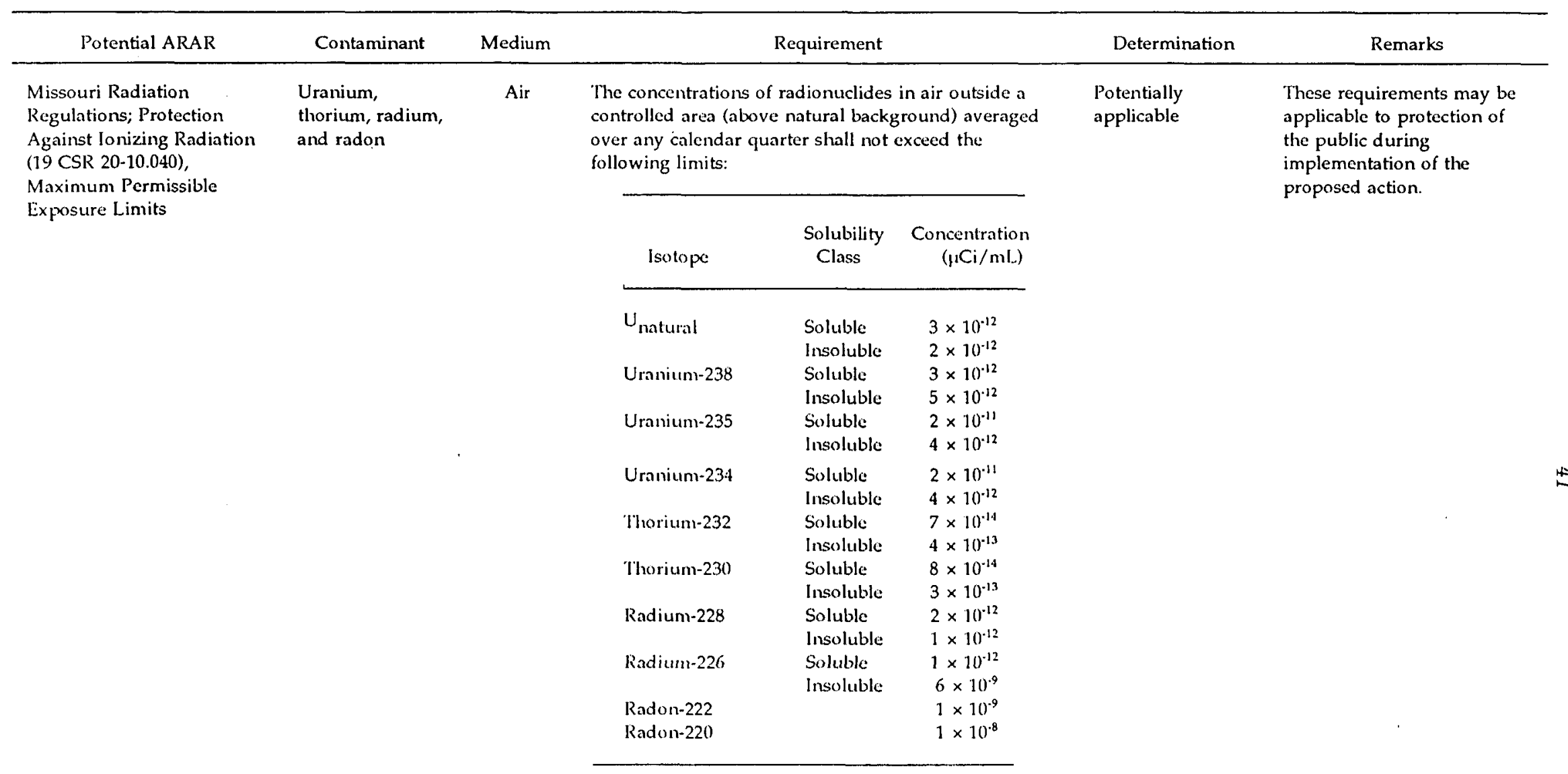


TABLE A.2 (Cont'd)

\begin{tabular}{|c|c|c|c|c|c|c|c|c|}
\hline Potential ARAR & Contaminant & Medium & \multicolumn{4}{|c|}{ Requirement } & Determination & Remarks \\
\hline \multirow[t]{5}{*}{$\begin{array}{l}\text { Radiation Protection of the } \\
\text { Public and the Environment } \\
\text { (DOE Order 5400.5) }\end{array}$} & \multirow[t]{5}{*}{$\begin{array}{l}\text { Uranium, } \\
\text { thorium, and } \\
\text { radium }\end{array}$} & \multirow[t]{5}{*}{ Air } & \multicolumn{4}{|c|}{$\begin{array}{l}\text { Residual concentrations of radionuclides in air in } \\
\text { uncontrolled areas are limited to the following. (For } \\
\text { known mixtures of radionuclides, the sum of the ratios } \\
\text { of the observed concentration of each radionuclide to } \\
\text { its corresponding limit shall not exceed } 1.0 \text {.) }\end{array}$} & To be considered & $\begin{array}{l}\text { Although not promulgated } \\
\text { standards, these constitute } \\
\text { requirements for protection } \\
\text { of the public with which the } \\
\text { proposed action will comply. }\end{array}$ \\
\hline & & & \multicolumn{4}{|c|}{$\begin{array}{l}\text { Derived Concentration Guide } \\
(\mu \mathrm{Ci} / \mathrm{mL})\end{array}$} & & \\
\hline & & & Isotope & $\mathrm{D}$ & W & $\mathrm{Y}$ & & \\
\hline & & & $\begin{array}{l}\text { Uranium-238 } \\
\text { Uranium-235 } \\
\text { Uranium-234 } \\
\text { Thorium-232 } \\
\text { Thorium-230 } \\
\text { Radium-228 } \\
\text { Radium-226 }\end{array}$ & $\begin{array}{l}5 \times 10^{-12} \\
5 \times 10^{-12} \\
4 \times 10^{-12} \\
\quad b \\
= \\
= \\
=\end{array}$ & $\begin{array}{l}2 \times 10^{-12} \\
2 \times 10^{-12} \\
2 \times 10^{-12} \\
7 \times 10^{-15} \\
4 \times 10^{-14} \\
3 \times 10^{-12} \\
1 \times 10^{-12}\end{array}$ & $\begin{array}{l}1 \times 10^{-13} \\
1 \times 10^{-13} \\
9 \times 10^{-14} \\
1 \times 10^{-14} \\
5 \times 10^{-14} \\
- \\
-\end{array}$ & & \\
\hline & & & \multicolumn{4}{|c|}{$\begin{array}{l}{ }^{\mathrm{a}} \mathrm{D}, \mathrm{W} \text {, and } \mathrm{Y} \text { represent lung retention classes; } \\
\text { removal half-times assigned to the compounds } \\
\text { with classes } \mathrm{D}, \mathrm{W} \text {, and } \mathrm{Y} \text { are } 0.5,50 \text {, and } 500 \text { days, } \\
\text { respectively. Exposure conditions assume an } \\
\text { inhalation rate of } 8,400 \mathrm{~m}^{3} \text { of air per year (based } \\
\text { on an exposure over } 24 \text { hours per day, } 365 \text { days } \\
\text { per year). } \\
{ }^{\mathrm{b}} \mathrm{A} \text { hyphen indicates that no limit has been } \\
\text { established. }\end{array}$} & & \\
\hline
\end{tabular}




\section{TABLE A.2 (Cont'd)}

\begin{tabular}{|c|c|c|c|c|c|c|}
\hline Potential ARAR & Contaminant & Medium & \multicolumn{2}{|l|}{ Requirement } & Determination & Remarks \\
\hline \multirow{4}{*}{$\begin{array}{l}\text { Occupational Safety and } \\
\text { Health Ad ministration } \\
\text { Standards; Occupational } \\
\text { Health and Environmental } \\
\text { Control (29 CFR 1910; } \\
\text { 1910.96), Subpart G, } \\
\text { Ionizing Radiation }\end{array}$} & \multirow[t]{4}{*}{ Radiation } & \multirow[t]{4}{*}{ Any } & \multicolumn{2}{|c|}{$\begin{array}{l}\text { The dose per calendar quarter resulting from exposure } \\
\text { to radiation in a restricted area from sources in that } \\
\text { area is limited to the following: }\end{array}$} & \multirow[t]{4}{*}{ Not an ARAR } & \multirow{4}{*}{$\begin{array}{l}\text { These requirements are part } \\
\text { of an employee protection } \\
\text { law (rather than an environ- } \\
\text { mental law) with which } \\
\text { CERCL.A response actions } \\
\text { should comply. Therefore, } \\
\text { these requirements are not } \\
\text { subject to evaluation for } \\
\text { attainment or waiver as part } \\
\text { of the ARAR process. They } \\
\text { are listed in this table to } \\
\text { identify requirements for } \\
\text { worker protection with } \\
\text { which the proposed action } \\
\text { will comply. }\end{array}$} \\
\hline & & & Part of Body & $\begin{array}{l}\text { Dose } \\
(r e m)\end{array}$ & & \\
\hline & & & $\begin{array}{l}\text { Whole body: head and trunk; } \\
\text { active blood-forming organs; } \\
\text { lens of eyc; or gonads } \\
\text { Hands and forearms; feet } \\
\text { and ankles }\end{array}$ & $183 / 4$ & & \\
\hline & & & Skin of whole body & $71 / 2$ & & \\
\hline
\end{tabular}

The occupational exposure of an individual younger than 18 is restricted to $10 \%$ of these limits; the wholebody dose to a worker shall not exceed $3 \mathrm{rem}$ in a calendar quarter, and when added to the cumulative occupational dose may not exceed $5(\mathrm{~N}-18) \mathrm{rem}$, where $\mathrm{N}$ is the age of the exposed individual. 
TABLE A.2 (Cont'd)

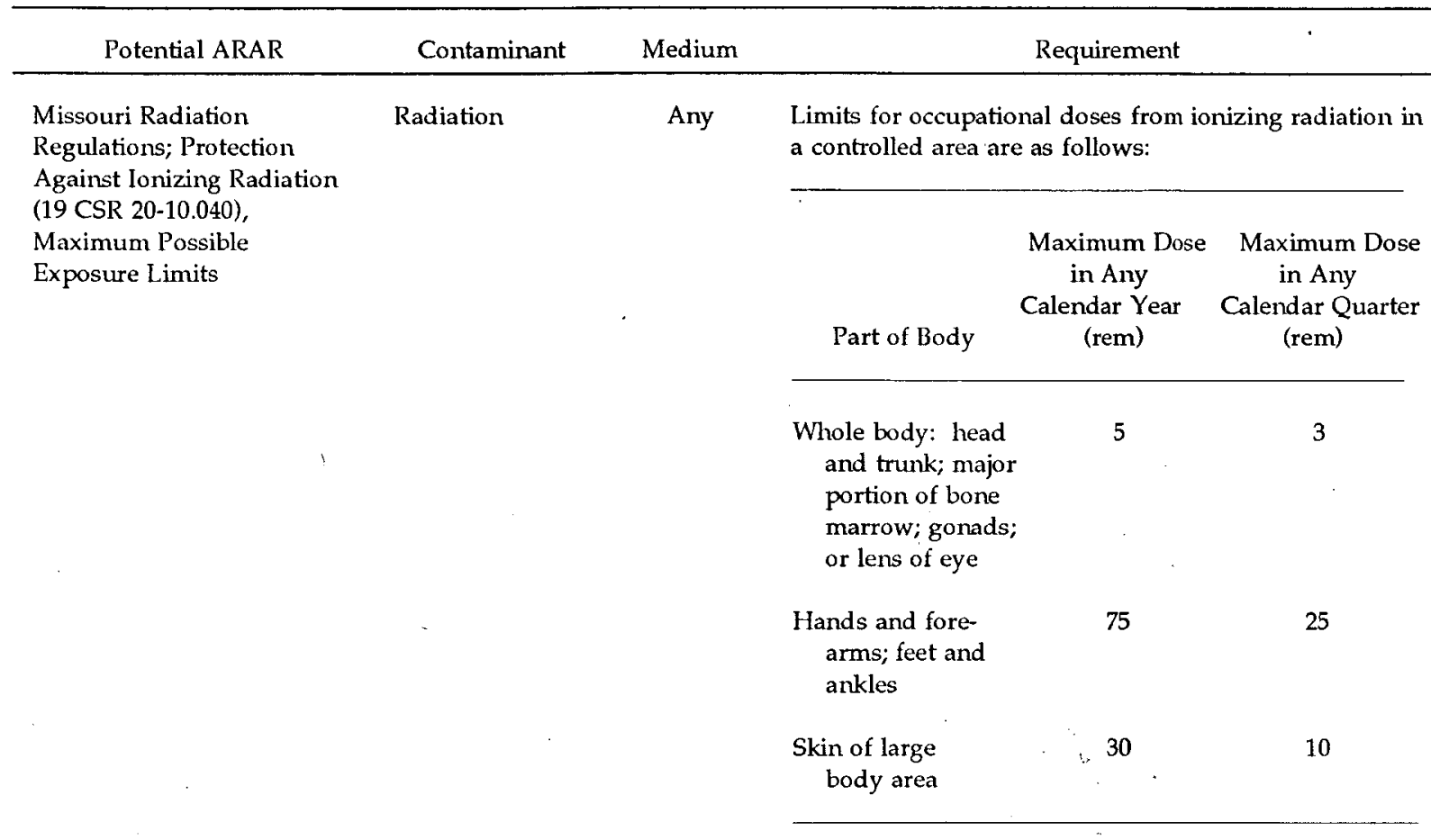

Also, the whole-body dose added to the cumulative occupational dose must not exceed $5(\mathrm{~N}-18)$ rem, where $\mathrm{N}$ is the age of the exposed individual

Missouri Radiation

Regulations; Protection

Against Ionizing Radiation

(19 CSR 20-10.050),

Personnel Monitoring and

Radiation Surveys
Radiation

Any

Personnel monitoring and radiation surveys are required for each worker for whom there is any

reasonable possibility of receiving a weekly dose from

all radiation exceeding $50 \mathrm{mrem}$, taking into

consideration the use of protective gloves and

radiation-limiting devices. An exemption from routine

monitoring may be granted under certain conditions.
Determination

Remark

These requirements are part of an employee protection law (rather than an environmental law) with which CERCLA response actions

should comply; hence, they are not subject to the ARAR process. However, they constitute requirements for worker protection with which the proposed action will comply.

Not an ARAR

These requirements are part of an employee protection law (rather than an environmental law) with which

CERCLA response action

should comply; hence, they are not subject to the ARAR process. However, they constitute requirements for worker protection with which the proposed action will comply. 


\section{TABLE A.2 (Cont'd)}

\begin{tabular}{|c|c|c|c|c|c|}
\hline Potential ARAR & Contaminant & Medium & Requirement & Determination & Remarks \\
\hline $\begin{array}{l}\text { Radiation Protection for } \\
\text { Occupational Workers (DOE } \\
\text { Order 5480.11) }\end{array}$ & Radiation & Any & $\begin{array}{l}\text { The effective dose equivalent received by any member } \\
\text { of the public entering a controlled area is limited to } \\
100 \mathrm{mrem} / \mathrm{yr} \text {. Limiting values for the assessed dose } \\
\text { from exposure of workers to radiation are as follows. } \\
\text { (These valucs represent maximum limits; it is DOE } \\
\text { policy to maintain radiation exposures as far below } \\
\text { these limits as is reasonably achievable.) }\end{array}$ & To be considered & $\begin{array}{l}\text { Although not promulgated } \\
\text { standards, these constitute } \\
\text { requirements for protection } \\
\text { from radionuclide emissions } \\
\text { in a controlled area with } \\
\text { which the proposed action } \\
\text { will comply. }\end{array}$ \\
\hline
\end{tabular}

\begin{tabular}{|c|c|}
\hline Radiation Effect & $\begin{array}{c}\text { Annual } \\
\text { Dose Equivalent } \\
\text { (rem) }\end{array}$ \\
\hline Stochastic effects & $5^{\mathrm{a}}$ \\
\hline \multicolumn{2}{|l|}{ Nonstochastic effects } \\
\hline L.ens of eye & 15 \\
\hline $\begin{array}{l}\text { Organ, extremity, } \\
\text { or tissuc including } \\
\text { skin of whole body }\end{array}$ & 50 \\
\hline $\begin{array}{l}\text { Unborn child, entire } \\
\text { gestation period }\end{array}$ & 0.5 \\
\hline
\end{tabular}


TABLE A.2 (Cont'd)

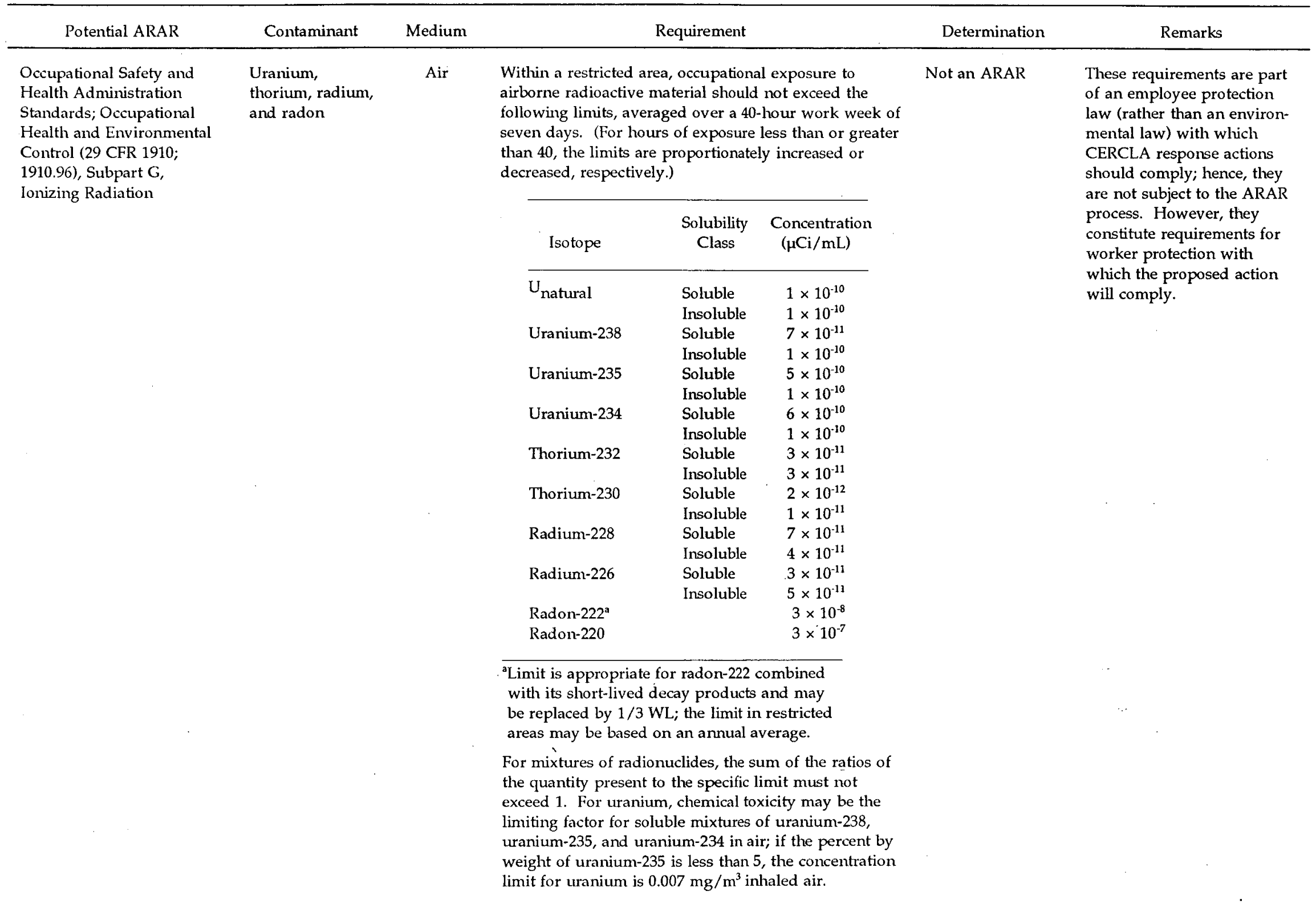




\section{TABLE A.2 (Cont'd)}

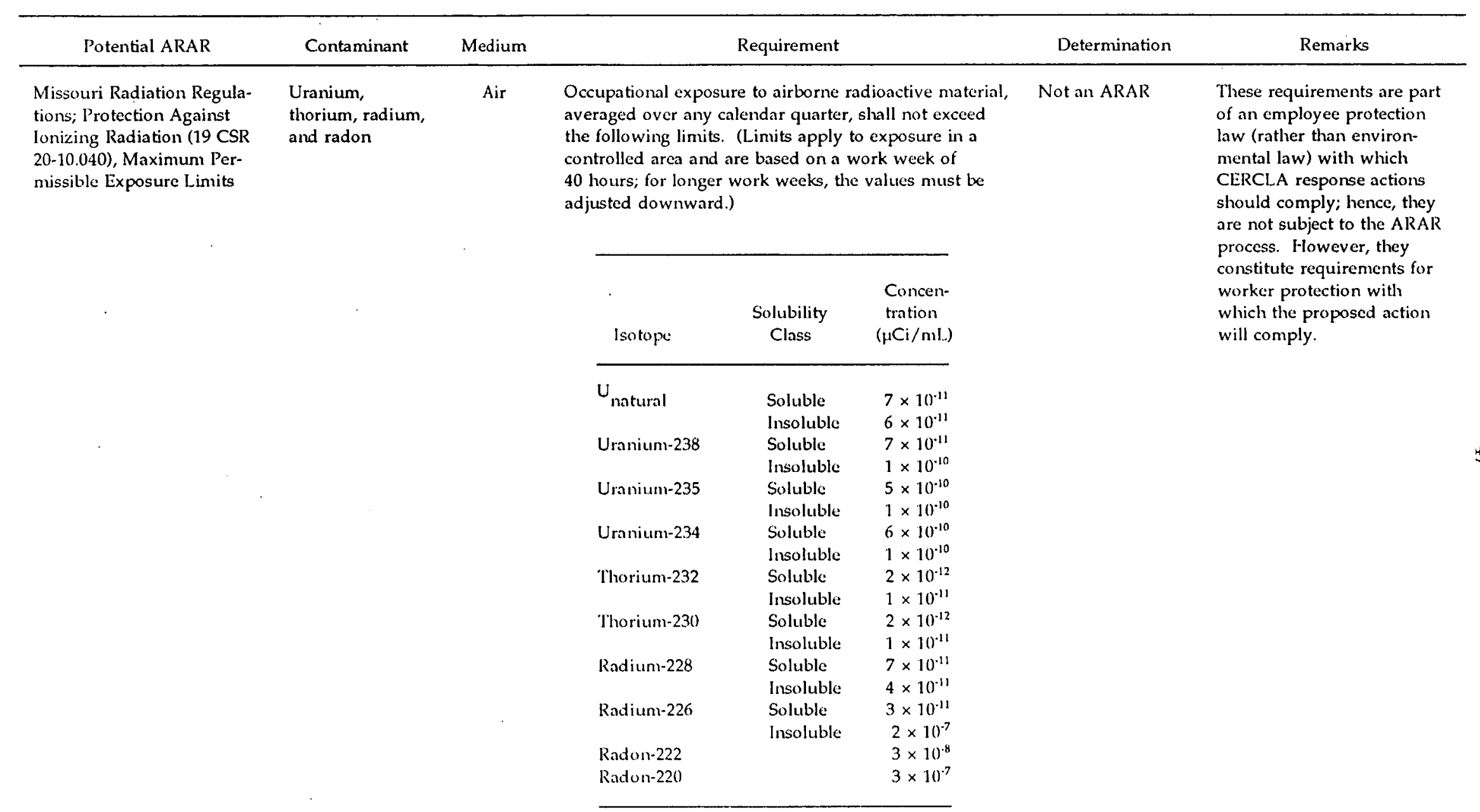


TABLE A.2 (Cont'd)

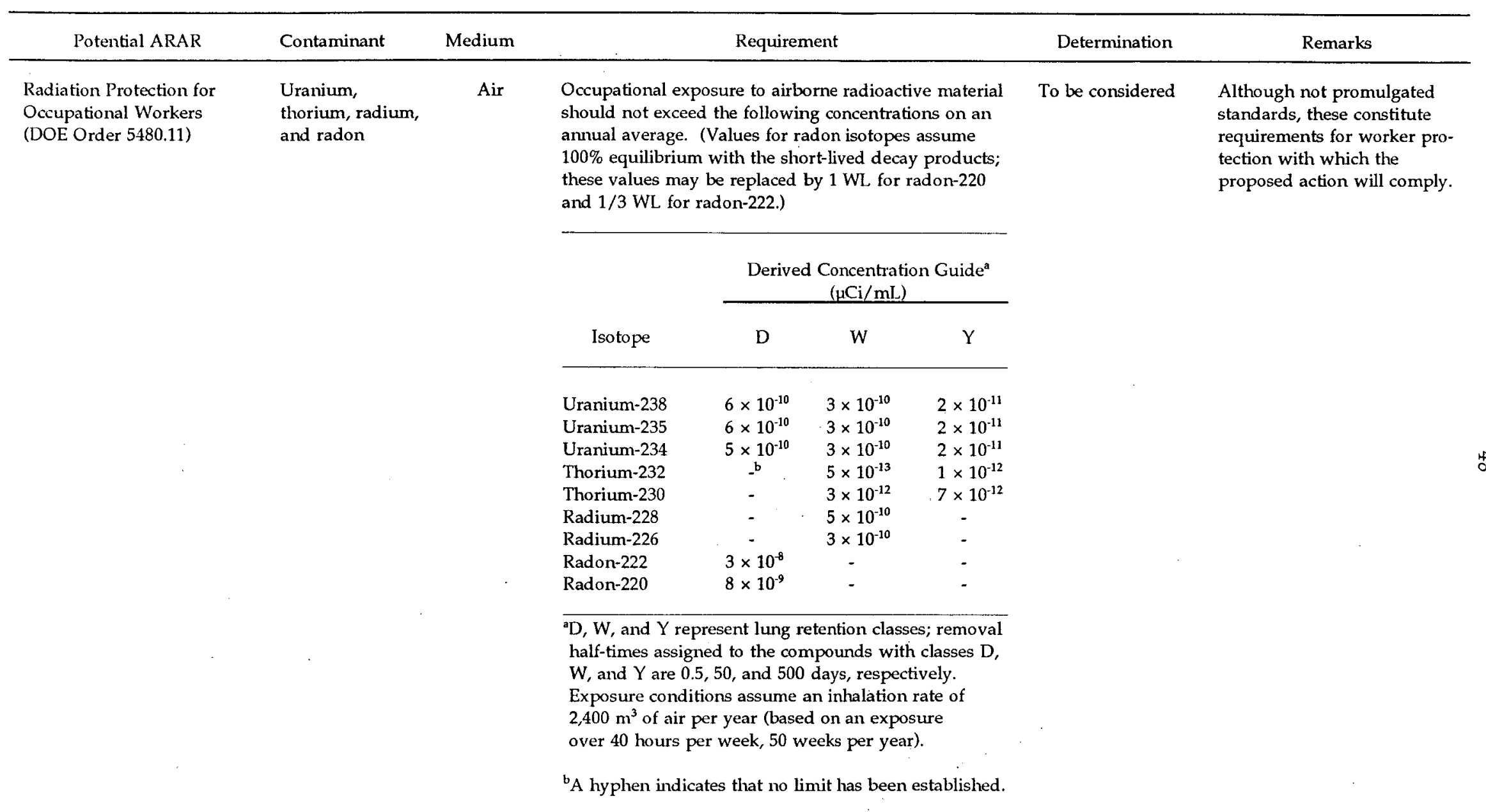


TABLE A.2 (Cont'd)

\begin{tabular}{|c|c|c|c|c|c|}
\hline Potential ARAR & Contaminant & Medium & Requirement & Determination & Remarks \\
\hline $\begin{array}{l}\text { Clean Air Act, as amended } \\
\text { (42 USC 7401-7642); } \\
\text { National Primary and } \\
\text { Secondary Ambient Air } \\
\text { Quality Standards } \\
\text { (40 Cl:R 50) }\end{array}$ & $\begin{array}{l}\text { Particulate } \\
\text { matter, lead }\end{array}$ & Air & $\begin{array}{l}\text { For a major stationary source (see } 40 \mathrm{CFR} \\
52.2(\mathrm{~b})(1)(\mathrm{i})(\mathrm{a})) \text { that emits }>250 \text { tons } / \mathrm{yr} \text { of any regulated } \\
\text { pollutant or }>100 \text { tons } / \mathrm{yr} \text { of a regulated pollutant for } \\
\text { which the area is designated as non-attainment, } \\
\text { particulate matter less than } 10 \mu \mathrm{m} \text { in diameter ( } \mathrm{PM}-10) \\
\text { shall not exceed a } 24 \text {-hour average concentration of } \\
150 \mu \mathrm{g} / \mathrm{m}^{3} \text { or an annual arithmetic mean of } 50 \mu \mathrm{g} / \mathrm{m}^{3} \text {. } \\
\text { The standard for lead and its compounds, as elemental } \\
\text { lead, is } 1.5 \mu \mathrm{g} / \mathrm{m}^{3} \text { as the maximum arithmetic mean } \\
\text { averaged over one calendar quarter. }\end{array}$ & Not an ARAR & $\begin{array}{l}\text { These requirements do not } \\
\text { apply directly to source- } \\
\text { specific emissions; rather, } \\
\text { they are national limitations } \\
\text { on ambient concentrations. } \\
\text { However, they will be } \\
\text { addressed in controlling } \\
\text { emissions of particulates and } \\
\text { lead that could result from } \\
\text { implementation of the pro- } \\
\text { posed action. }\end{array}$ \\
\hline $\begin{array}{l}\text { Missouri Air Conservation } \\
\text { Law; l'ublic Health and } \\
\text { Welfare (RSMo. Title 12, } \\
\text { 203.055), Comnission nay } \\
\text { adopt rules for compliance } \\
\text { with federal law -- } \\
\text { suspension, reinstatement }\end{array}$ & $\begin{array}{l}\text { Any regulated } \\
\text { under federal } \\
\text { Clean Air Act }\end{array}$ & Air & $\begin{array}{l}\text { Standards and guidelines promulgated to ensure that } \\
\text { Missouri is in compliance with the Clean Air Act are } \\
\text { not to be any stricter than those required under that act } \\
\text { (see related discussion of } 40 \text { CFR 50). }\end{array}$ & Not an $A R A R$ & $\begin{array}{l}\text { These requirements do not } \\
\text { apply dircetly to source- } \\
\text { specific enissions; rather, } \\
\text { they are national limitations } \\
\text { on anbient concentrations. } \\
\text { However, they will be } \\
\text { addressed in controlling } \\
\text { emissions of particulates and } \\
\text { lead that could result from } \\
\text { implementation of the pro- } \\
\text { posed action. }\end{array}$ \\
\hline $\begin{array}{l}\text { Missouri Air Quality Stan- } \\
\text { dards; Air Quality Stan- } \\
\text { dards, Definitions, Samp- } \\
\text { ling, and Reference } \\
\text { Methods, and Air Pollution } \\
\text { Control Regulations for the } \\
\text { State of Missouri (10 CSR } \\
\text { 10-6.010), Ambient Air } \\
\text { Quality }\end{array}$ & $\begin{array}{l}\text { Particulate } \\
\text { matter }(P M-10) \\
\text { lead }\end{array}$ & $\Lambda \mathrm{ir}$ & $\begin{array}{l}\text { Concentrations of } P M-10 \text { are limited to an amual } \\
\text { arithnetic mean of } 50 \mu \mathrm{g} / \mathrm{m}^{3} \text { and a } 24-\mathrm{hour} \text { average of } \\
150 \mu \mathrm{g} / \mathrm{m}^{3} \text {. The standard for lead is } 1.5 \mu \mathrm{g} / \mathrm{m}^{3} \text { as the } \\
\text { arithmetic mean averaged over one calendar quarter. }\end{array}$ & Not an ARAR & $\begin{array}{l}\text { These requirements do not } \\
\text { apply dircetly to source- } \\
\text { specific emissions; rather, } \\
\text { they are national limitations } \\
\text { on ambient concentrations. } \\
\text { However, they will be } \\
\text { addressed in controlling } \\
\text { emissions of particulates and } \\
\text { lend that could result from } \\
\text { implementation of the pro- } \\
\text { posed action. }\end{array}$ \\
\hline
\end{tabular}


TABLE A.2 (Cont'd)

\begin{tabular}{l} 
Potential ARAR \\
\hline Missouri Air Pollution Con- \\
trol Regulations; Air Quality \\
Standards and Air Pollution \\
Control Regulations for the \\
St. Louis Metropolitan Area \\
(10 CSR 10-5.090), Restric- \\
tion of Emission of Particu- \\
late Matter from Industrial \\
Processes
\end{tabular}

Missouri Air Pollution Control Regulations; Air Quality Standards and Air Pollution Control Regulations for the St. Louis Metropolitan Area (10 CSR 10-5.090), Restriction of Emission of Visible Air Contaminants

Missouri Air Pollution Control Regulations; Air Quality Standards and Air Pollution Control Regulations for the St. Louis Metropolitan Area (10 CSR 10-5.100), Pre-

venting Particulate Matter

from Becoming Airborne
Contaminant

Medium

Requirement

Particulate

matter

Air

Particulate matter from any industrial source shall not exceed a concentration of $0.30 \mathrm{grain} / \mathrm{ft}^{3}$ of exhaust gas certain activities are exempted (e.g., grinding, crushing, and classifying operations at a rock quarry).

\section{Particulate}

matter

Emissions of particulate matter $(<25 \mathrm{lb} / \mathrm{h})$ from any single source, not including uncombined water, may not be darker than the shade of density designated as No. 2 on the Ringelmann Chart, or $40 \%$ opacity.

No person shall permit the handling, transport, or storage of any naterial in a way that allows unnecessary amounts of fugitive particulate matter to become airborne and that results in at least one complaint being filed. To prevent particulate matter from

becoming airborne during construction, use, repair, or demolition of a road, driveway, or open area, the following measures may be required: paving or frequent cleaning of roads, applying dust-free surfaces or water, and planting and maintaining a vegetative ground cover. (Unpaved public roads in uuincorporated areas that are in compliance with particulate matter standards are excluded.)
Determination Remarks

Not an ARAR

These requirements are neither applicable nor

relevant and appropriate because no industrial processes are involved in the proposed action. However

they will be addressed in

controlling particulate

emissions that could be

generated during

implementation.

Not an ARAR

These requirements are neither applicable nor relevant and appropriate because the site does not constitute an emission source, per the regulatory definition. However, they will be addressed in controlling particulate emissions that could result from implementation of the proposed action.

Potentially relevant and appropriate

Although not directly applicable because vehicle routes are targeted by this regulation and the exclusion is pertinent, these requirements may be relevant and appropriate to the control of particulate emissions that could result from implementation of the proposed action. 


\section{TABLE A.2 (Cont'd)}

\begin{tabular}{|c|c|c|c|c|c|}
\hline Potential ARAR & Contaminant & Medium & Requirement & Determination & Remarks \\
\hline $\begin{array}{l}\text { Missouri Air Pollution Con- } \\
\text { trol Regulations; Air Quality } \\
\text { Standards and Air Pollution } \\
\text { Control Regulations for the } \\
\text { St. Louis Metropolitan Area } \\
\text { (10 CSR 10-5.180), Emission } \\
\text { of Visible Air Contaninants } \\
\text { from lnternal Combustion } \\
\text { Engines }\end{array}$ & $\begin{array}{l}\text { Particulate } \\
\text { matter }\end{array}$ & Air & $\begin{array}{l}\text { Visible air contaminants (other than uncombined water) } \\
\text { shall not be released from an internal combustion } \\
\text { engine for more than } 10 \text { seconds at any one time. }\end{array}$ & $\begin{array}{l}\text { Potentially } \\
\text { applicable }\end{array}$ & $\begin{array}{l}\text { These requirements may be } \\
\text { applicable to particulates } \\
\text { released from any internal } \\
\text { combustion engines used } \\
\text { during the proposed action. }\end{array}$ \\
\hline $\begin{array}{l}\text { National Emission Stan- } \\
\text { dards for Hazardous Air } \\
\text { Pollutants (40 CFR 61), } \\
\text { Subpart M, National Emis- } \\
\text { sion Standard for Asbestos }\end{array}$ & Asbestos & Air & $\begin{array}{l}\text { Warning signs shall be posted, and discharge of visible } \\
\text { emissions shall not occur during the collection, pro- } \\
\text { cessing, packaging, transporting, or deposition of } \\
\text { friable asbestos-containing material. }\end{array}$ & $\begin{array}{l}\text { Potentially } \\
\text { applicable }\end{array}$ & $\begin{array}{l}\text { This requirement may be } \\
\text { applicable to protection of } \\
\text { the public if any asbestos } \\
\text { emissions result from the } \\
\text { specific response activity } \\
\text { (e.g., for a building } \\
\text { renovation or decontami- } \\
\text { nation activity). }\end{array}$ \\
\hline $\begin{array}{l}\text { Toxic Substances Control } \\
\text { Act, as amended (15 USC } \\
26(17-2629 ; \text { Pl 94-469 et seq.); } \\
\text { Asbestos (40 ClR 763), } \\
\text { Subpart G, Asbestos } \\
\text { Abatement Projects }\end{array}$ & Asbestos & Air & $\begin{array}{l}\text { Programs for worker training and protection (via } \\
\text { clothing and equipment) shall be implemented, and the } \\
\text { permissible exposure limit for asbestos is } 0.2 \mathrm{fiber} / \mathrm{cm}^{3} \\
\text { of air as an 8-hour time-weighted average. }\end{array}$ & Not an $A R A R$ & $\begin{array}{l}\text { These requirements are part } \\
\text { of an employee protection } \\
\text { law (rather than an environ- } \\
\text { mental law) with which } \\
\text { CERCLA response actions } \\
\text { should comply; hence, they } \\
\text { are not subject to the ARAR } \\
\text { process. However, they } \\
\text { constitute requirements for } \\
\text { worker protection with } \\
\text { which the proposed action } \\
\text { will comply. }\end{array}$ \\
\hline
\end{tabular}




\section{TABLE A.2 (Cont'd)}

\begin{tabular}{|c|c|c|c|c|c|}
\hline Potential ARAR & Contaminant & Medium & Requirement & Determination & Remarks \\
\hline $\begin{array}{l}\text { Occupational Safety and } \\
\text { Health Administration } \\
\text { Standards; Occupational } \\
\text { Health and Environmental } \\
\text { Control (29 CFR 1910; 1910, } \\
\text { 1001), Subpart G, Asbestos } \\
\text { Tremolite, Anthophyllite, } \\
\text { and Actinolite }\end{array}$ & Asbestos & Air & $\begin{array}{l}\text { Various asbestos-management activities are required for } \\
\text { worker protection, including monitoring, timely } \\
\text { response to releases, and the use of high-efficiency- } \\
\text { particulate-air (HEPA)-filtered equipment for } \\
\text { vacuuming. The permissible occupational exposure } \\
\text { limit for asbestos as an 8-hour time-weighted average is } \\
0.2 \text { fiber } / \mathrm{cm}^{3} \text { of air. }\end{array}$ & Not an ARAR & $\begin{array}{l}\text { These requirements are part } \\
\text { of an employee protection } \\
\text { law (rather than an environ- } \\
\text { mental law) with which } \\
\text { CERCLA response actions } \\
\text { should comply; hence, they } \\
\text { are not subject to the ARAR } \\
\text { process. However, they } \\
\text { constitute requirements for } \\
\text { worker protection with } \\
\text { which the proposed action } \\
\text { will comply. }\end{array}$ \\
\hline $\begin{array}{l}\text { Occupational Safety and } \\
\text { Health Administration } \\
\text { Construction Industry } \\
\text { Standards (29 CFR 1926) }\end{array}$ & Asbestos & Air & $\begin{array}{l}\text { Worker health and safety standards include a limit for } \\
\text { occupational exposure to asbestos of } 0.2 \mathrm{fiber} / \mathrm{cm}^{3} \text { of } \\
\text { air as an } 8 \text {-hour time-weighted average, with an action } \\
\text { level of } 0.1 \mathrm{fiber} / \mathrm{cm}^{3} \text { and a short-term ( } 30 \text {-ninute) limit } \\
\text { of } 1 \mathrm{fiber} / \mathrm{cm}^{3} \text { of air (fibers }>5 \mu \mathrm{m} \text { ). }\end{array}$ & Not an ARAR & $\begin{array}{l}\text { These requirements are part } \\
\text { of an employee protection } \\
\text { law (rather than an environ- } \\
\text { mental law) with which } \\
\text { CERCLA response actions } \\
\text { should comply; hence, they } \\
\text { are not subject to the ARAR } \\
\text { process. However, they } \\
\text { constitute requirements for } \\
\text { worker protection with } \\
\text { which the proposed action } \\
\text { will comply. }\end{array}$ \\
\hline $\begin{array}{l}\text { Occupational Safety and } \\
\text { Health Administration } \\
\text { Standards; Occupational } \\
\text { Health and Environmental } \\
\text { Control (29 CFR 1910; } \\
\text { 1910.95), Subpart G, } \\
\text { Occupational Noise } \\
\text { Exposure }\end{array}$ & Noise & Air & $\begin{array}{l}\text { The permissible occupational exposure level for noise is } \\
90 \mathrm{dBa} \text { (slow response) for an } 8 \text {-hour day; with } \\
\text { decreasing times of exposure, the levels increase to } \\
115 \mathrm{dBa} \text { per } 1 / 4 \text {-hour day. }\end{array}$ & Not an ARAR & $\begin{array}{l}\text { These requirements are part } \\
\text { of an employee protection } \\
\text { law (rather than an environ- } \\
\text { mental law) with which } \\
\text { CERCLA response actions } \\
\text { should comply; hence, they } \\
\text { are not subject to the ARAR } \\
\text { process. However, they con- } \\
\text { stitute requirements for } \\
\text { worker protection with } \\
\text { which the proposed action } \\
\text { will comply. }\end{array}$ \\
\hline
\end{tabular}




\section{TABLE A.3 Potential Action-Specific Requirements}

\begin{tabular}{|c|c|c|c|c|}
\hline Potential ARAR & Action & Requirement & $\begin{array}{c}\text { Preliminary } \\
\text { Determination }\end{array}$ & Remarks \\
\hline $\begin{array}{l}\text { U.S. Nuclear Regulatory Com- } \\
\text { nission Guidelines for Decon- } \\
\text { tamination of Facilities and } \\
\text { Equipment Prior to Release } \\
\text { for Unrestricted Use or } \\
\text { Termination of Licenses for } \\
\text { Byproduct, Source, or Special } \\
\text { Nuclear Material }\end{array}$ & $\begin{array}{l}\text { Decontami- } \\
\text { nation }\end{array}$ & $\begin{array}{l}\text { Structural debris associated with licensed by-product, source, } \\
\text { or special nuclear material that is released for reuse without } \\
\text { radiological restrictions should be decontaninated to specified } \\
\text { levels. The allowable total residual surface contamination } \\
\text { levels for transuranics, iodine-125, iodine- } 129 \text {, radium-226, } \\
\text { actinium- } 227 \text {, radium-228, thorium-228, thorium-230, and } \\
\text { protactinium-231 are as follows: average, } 100 \mathrm{dpm} / 100 \mathrm{~cm}^{2} \text {; } \\
\text { maximum } 300 \mathrm{dpm} / 100 \mathrm{~cm}^{2} \text {; and removable, } 20 \mathrm{dpm} / 100 \mathrm{~cm}^{2} \text {. }\end{array}$ & $\begin{array}{l}\text { Potentially } \\
\text { applicable }\end{array}$ & $\begin{array}{l}\text { These requirements are not appli- } \\
\text { cable because the SLDS is not a } \\
\text { nuclear facility licensed by the } \\
\text { U.S. Nuclear Regulatory Com- } \\
\text { nission. Furthermore, most of } \\
\text { the requirements listed in the } \\
\text { guidelines have been incor- } \\
\text { porated into DOE Order } 5400.5 \text {, } \\
\text { with which the proposed action } \\
\text { will comply (sce later entry in } \\
\text { this table); however, this Order } \\
\text { does not include the require- } \\
\text { ments shown here. These } \\
\text { requirements may be relevant } \\
\text { and appropriate to the release of } \\
\text { structural material for reuse } \\
\text { without radiological restrictions. }\end{array}$ \\
\hline $\begin{array}{l}\text { Termination of Operating } \\
\text { Licenses for Nuclear Reactors } \\
\text { (U.S. Nuclear Regulatory } \\
\text { Commission Reulatory } \\
\text { Guide 1.86) }\end{array}$ & $\begin{array}{l}\text { Decontani- } \\
\text { nation }\end{array}$ & $\begin{array}{l}\text { Structural debris associated with licensed reactors that is } \\
\text { released for reuse without radiological restrictions should be } \\
\text { decontaminated to specified levels. }\end{array}$ & $\begin{array}{l}\text { Potentially } \\
\text { relcuant and } \\
\text { appropriate }\end{array}$ & $\begin{array}{l}\text { These requirements are not appli- } \\
\text { cable because the SLDS is not a } \\
\text { nuclear reactor licensed by the } \\
\text { U.S. Nuclear Regulatory Com- } \\
\text { mission. Furthermore, most of } \\
\text { the requirements listed in this } \\
\text { regulatory guide have been incor- } \\
\text { porated into DOE Order } 5400.5 \text {, } \\
\text { with which the proposed action } \\
\text { will comply. The allowable sur- } \\
\text { face contamination levels in- } \\
\text { cluded in this regulatory guide } \\
\text { are identical to those discussed in } \\
\text { the previous entry in this table. }\end{array}$ \\
\hline
\end{tabular}


TABLE A.3 (Cont'd)

\begin{tabular}{|c|c|c|c|c|c|c|c|}
\hline Potential ARAR & Action & & Requir & tent & & $\begin{array}{l}\text { Preliminary } \\
\text { Determination }\end{array}$ & Remarks \\
\hline \multirow[t]{5}{*}{$\begin{array}{l}\text { Radiation Protection of the } \\
\text { Public and the Environment } \\
\text { (DOE Order 5400.5) }\end{array}$} & \multirow[t]{5}{*}{$\begin{array}{l}\text { Decontami- } \\
\text { nation }\end{array}$} & \multicolumn{4}{|c|}{$\begin{array}{l}\text { Structural debris that is released from DOE facilities for reuse } \\
\text { without radiological restrictions should be decontaminated to } \\
\text { the following levels. }\end{array}$} & \multirow[t]{5}{*}{$\begin{array}{l}\text { To be con- } \\
\text { sidered }\end{array}$} & \multirow{5}{*}{$\begin{array}{l}\text { Although not promulgated } \\
\text { standards, these constitute } \\
\text { requirements for protection of the } \\
\text { public with which the proposed } \\
\text { action will comply. }\end{array}$} \\
\hline & & & \multicolumn{3}{|c|}{$\begin{array}{l}\text { Allowable Total Residual Surface } \\
\text { Contamination }\left(\mathrm{dpm} / 100 \mathrm{~cm}^{2}\right)^{\mathrm{a}}\end{array}$} & & \\
\hline & & Radionuclides $^{b}$ & Average $^{c_{, d}}$ & Maximum $^{e}$ & Removable $^{d, f}$ & & \\
\hline & & $\begin{array}{l}\text { Transuranics, } \\
\text { iodine-125, } \\
\text { iodine-129, } \\
\text { radium-226, } \\
\text { actinium-227, } \\
\text { radium-228, } \\
\text { thorium-228, } \\
\text { thorium-230, } \\
\text { protactinium-231 }\end{array}$ & Reserved & Reserved & Reserved & & \\
\hline & & $\begin{array}{l}\text { Thorium-natural, } \\
\text { strontium-90, } \\
\text { iodine-126, } \\
\text { iodine-131, } \\
\text { iodine-133, } \\
\text { radium-223, } \\
\text { radium-224, } \\
\text { uranium-232, } \\
\text { thorium-232 }\end{array}$ & 1,000 & 3,000 & 200 & & \\
\hline
\end{tabular}


TABLE A.3 (Cont'd)

\begin{tabular}{|c|c|c|c|c|c|}
\hline Potential ARAR & Action & \multicolumn{4}{|c|}{ Requirement } \\
\hline \multirow[t]{6}{*}{ (Cont'd) } & & . & & & \\
\hline & & & \multicolumn{3}{|c|}{$\begin{array}{l}\text { Allowable Total Residual Surface } \\
\text { Contanination }\left(\mathrm{dpm} / 100 \mathrm{~cm}^{2}\right)^{\mathrm{a}}\end{array}$} \\
\hline & & Radionuclides $^{b}$ & Average $e^{c, d}$ & Maximum ${ }^{\mathrm{c}}$ & Removabled,f \\
\hline & & $\begin{array}{l}\text { Uranium-natural, } \\
\text { uranium-235, } \\
\text { uranium-238, } \\
\text { and associated } \\
\text { decay products, } \\
\text { alpha emitters }\end{array}$ & 5,000 & 15,000 & 1,000 \\
\hline & & $\begin{array}{l}\text { Betn-gamma } \\
\text { emitters (radio- } \\
\text { nuclides with } \\
\text { decay modes } \\
\text { other than alpha } \\
\text { emission or } \\
\text { spontancous } \\
\text { fission) except } \\
\text { strontium-90 and } \\
\text { others noted } \\
\text { above }^{8}\end{array}$ & 5,000 & 15,000 & 1,000 \\
\hline & & $\begin{array}{l}{ }^{\circ} \text { As used in this } \\
\text { the rate of emiss } \\
\text { correcting the co } \\
\text { detector for back } \\
\text { associated with }\end{array}$ & $\begin{array}{l}\text { e, dpm (disiı } \\
\text { by radioacti } \\
\text { s per minue } \\
\text { und, efficier } \\
\text { instrumenta }\end{array}$ & $\begin{array}{l}\text { egrations per } \\
\text { nuaterial as } \\
\text { ieasured by } \\
\text {, and geome } \\
\text { n. }\end{array}$ & $\begin{array}{l}\text { linute) means } \\
\text { termined by } \\
\text { appropriate } \\
\text { ic factors }\end{array}$ \\
\hline
\end{tabular}

Preliminary

Determination

Remarks 
TABLE A.3 (Cont'd)

\begin{tabular}{|c|c|c|c|c|}
\hline Potential ARAR & Action & Requirement & $\begin{array}{c}\text { Preliminary } \\
\text { Determination }\end{array}$ & Remarks \\
\hline
\end{tabular}

(Cont'd)
${ }^{b}$ Where surface contamination by both alpha- and betagamma-emitting radionuclides exists, the limits established for alpha- and beta-gamma-emitting radionuclides should apply independently.

Measurements of average contamination should not be averaged over an area of more than $1 \mathrm{~m}^{2}$. For objects of smaller surface area, the average should be derived for each such object.

dThe average and maximum dose rates associated with surface contamination resulting from beta-gamma emitters should not exceed $0.2 \mathrm{mrad} / \mathrm{h}$ and $1.0 \mathrm{mrad} / \mathrm{h}$, respectively, at $1 \mathrm{~cm}$.

'The maximum contamination level applies to an area of not more than $100 \mathrm{~cm}^{2}$.

'The amount of removable material per $100 \mathrm{~cm}^{2}$ of surface area should be determined by wiping an area of that size with dry filter or soft absorbent paper (applying moderate pressure) and measuring the amount of radioactive material on the wipe with an appropriate instrument of known efficiency. When removable contamination on objects of surface area less than $100 \mathrm{~cm}^{2}$ is determined, the activity per unit area should be wiped. It is not necessary to use wiping techniques to measure removable contamination levels if direct scan surveys indicate that the total residual surface contamination levels are within the limits for removable contamination.

5This category of radionuclides includes mixed fission products, including strontium-90, that have been separated from other fission products or mixtures where the strontium-90 has been enriched. 


\section{TABLE A.3 (Cont'd)}

\begin{tabular}{cccc}
\hline & Preliminary & \\
Potential ARAR & Action & Requirement & Remarks \\
\hline
\end{tabular}

Noise Control Act, as amended;

Noise Pollution and Abatement Act

Occupational Safety and Healt

Administration Standards for

Hazardous Waste Operations and

Emergency Response (29 CFR

1910.120)

Radionctive Waste Management

(1)OE Order 5820.2A)

Radiation Protection of the Public and the Environment (DOE Order 5400.5
Construction The public must be protected from noises (e.g., Potentially and opera- that could result from construction and applicable tion operation activities) that jeopardize health or welfare.

Waste

management

General worker protection requirements are established, as are requirements for worker training and the development of an emergency response plan and a safety and health program for employees. In addition, procedures are established for hazardous waste operations -including decontamination and drum/container handling (e.g., for radioactive waste and asbestos).

Waste External exposure to radioactive waste

management (including releases) shall not result in an effective dose equivalent of $>25 \mathrm{mrem} / \mathrm{yr}$ to any member of the public; releases to the atmosphere are to meet the requirements of 40 CFR 61 (see related discussion in Table A.2); and an environmental monitoring program shall be implemented to address compliance with performance standards.

Interin

The control and stabilization features of a

waste storage

and

management
To be

considered

lo be considered storage facility should be designed to ensure an effective life of 50 years, with a minimum life of at least 25 years, to the extent reasonably achievable; site access controls should be designed to ensure an effective life of at least 25 years, to the extent reasonable; and periodic monitoring, shiclding, access restrictions, and safety measures nust be implemented to control the migration of radioactive nuterial, as appropriate.

Because equipment and vehicles would be involved in certain aspects of the proposed action, all pertinent requirements of the act will be followed.

Not an ARAR These requirements are part of an employee protection law (rather than an environmental law) with which CERCL.A response actions should comply; hence, they are not subject to the ARAR process. However, they constitute requirements for worker protection with which the proposed action will comply.

Although not promulgated standards, these constitute requirements with which the proposed action will comply. A monitoring program will be implemented during the proposed action

Although not promulgated standards, these constitute requirements with which the storage of wastes resulting from this action will comply. 
TABLE A.3 (Cont'd)

\begin{tabular}{|c|c|c|c|c|}
\hline Potential ARAR & Action & Requirement & $\begin{array}{l}\text { Preliminary } \\
\text { Determination }\end{array}$ & Remarks \\
\hline $\begin{array}{l}\text { Missouri Radiation Regulations; } \\
\text { Protection Against Ionizing } \\
\text { Radiation (19 CSR 20-10.070), } \\
\text { Storage of Radioactive Materials }\end{array}$ & $\begin{array}{l}\text { Radioactive } \\
\text { waste storage }\end{array}$ & $\begin{array}{l}\text { Radioactive materials must be stored in a } \\
\text { manner that will not result in the exposure of } \\
\text { any person, during routine access to a controlled } \\
\text { area, in excess of the limits identified in } 19 \text { CSR } \\
20-10.040 \text { (see related discussion for } \\
\text { contaminant-specific requirements); a facility } \\
\text { used to store materials that may emit radioactive } \\
\text { gases or airborne particulate matter must be } \\
\text { vented to ensure that the concentration of such } \\
\text { substances in the air does not constitute a } \\
\text { radiation hazard; and provisions must be made } \\
\text { to minimize the hazard to emergency workers in } \\
\text { the event of a fire, earthquatke, flood, or } \\
\text { windstorm. }\end{array}$ & $\begin{array}{l}\text { Potentially } \\
\text { applicable }\end{array}$ & $\begin{array}{l}\text { These requirements may be applicable to the } \\
\text { storage of certain material resulting from the } \\
\text { proposed action. }\end{array}$ \\
\hline $\begin{array}{l}\text { Missouri Radiation Regulations; } \\
\text { Protection Against Ionizing } \\
\text { Radiation (19 CSR 20-10.080), } \\
\text { Control of Radioactive } \\
\text { Contamination }\end{array}$ & $\begin{array}{l}\text { Waste } \\
\text { management }\end{array}$ & $\begin{array}{l}\text { All work shall be carried out under conditions } \\
\text { that minimize the potential spread of radioactive } \\
\text { material that could result in the exposure of any } \\
\text { person above any limit specified in } 19 \text { CSR 20- } \\
10.040 \text { (see related discussion in Table A.2). } \\
\text { Clothing and other personal contamination } \\
\text { should be monitored and removed according to } \\
\text { procedures established by a qualified expert; any } \\
\text { material contaminated to the degree that a } \\
\text { person could be exposed to radiation above any } \\
\text { limit specified in } 19 \text { CSR } 20-10.040 \text { should be } \\
\text { retained on-site until it can be decontaminated or } \\
\text { disposed of according to procedures established } \\
\text { by a qualified expert. }\end{array}$ & Not an ARAR & $\begin{array}{l}\text { These requirements are part of an employee } \\
\text { protection law (rather than an environmental } \\
\text { law) with which CERCLA response actions } \\
\text { should comply; hence, they are not subject to } \\
\text { the ARAR process. However, they constitute } \\
\text { requirements for worker protection with which } \\
\text { the proposed action will comply. }\end{array}$ \\
\hline
\end{tabular}




\section{TABLE A.3 (Cont'd)}

\begin{tabular}{|c|c|c|c|c|}
\hline Potential ARAR & Action & Requirement & $\begin{array}{l}\text { Preliminary } \\
\text { Determination }\end{array}$ & Remarks \\
\hline $\begin{array}{l}\text { National Emission Standards for } \\
\text { Hazardous Air Pollutants (40 } \\
\text { CIR 61), Subpart M, National } \\
\text { Emission Standard for Asbestos }\end{array}$ & $\begin{array}{l}\text { Asbestos } \\
\text { management }\end{array}$ & $\begin{array}{l}\text { Asbestos-containing material from manufac- } \\
\text { turing, demolition, renovation, spraying, and } \\
\text { fabricating operations slould be wet and sealed } \\
\text { in labeled, leak-tight containers to prepare for its } \\
\text { disposal. }\end{array}$ & $\begin{array}{l}\text { Potentially } \\
\text { applicable }\end{array}$ & $\begin{array}{l}\text { These requirements are considered potentially } \\
\text { applicable to the proposed action. (Note that } \\
\text { the disposal of asbestos-containing material is } \\
\text { beyond the scope of this action.) }\end{array}$ \\
\hline $\begin{array}{l}\text { Solid Waste Disposal Act, as } \\
\text { amended ( } 42 \text { USC } 6901 \text {, et seq.); } \\
\text { Identification and Listing of } \\
\text { Hazardous Waste ( } 40 \text { CFR } 261 \text { ) }\end{array}$ & $\begin{array}{l}\text { Hazardous } \\
\text { waste deter- } \\
\text { nination }\end{array}$ & $\begin{array}{l}\text { A waste must be evaluated to determine if it is a } \\
\text { hazardous waste, i.e., either a waste listed in this } \\
\text { requirement or a characteristic waste. A charac- } \\
\text { teristic waste is deternined by its (1) ignitability. } \\
\text { (defined by flash point, oxidizer, and other); } \\
\text { (2) corrosivity (defined by pl- } \leq 2 \text { or } \geq 12.5 \text {, rate of } \\
\text { steel corrosion, and other); ( } 3 \text { ) reactivity (defined } \\
\text { by instability, violent reaction with water, } \\
\text { explosivity, cyanide- or sulfide-bearing nature } \\
\text { with vapor generation potential, and other); or }\end{array}$ & $\begin{array}{l}\text { Potentially } \\
\text { applicable }\end{array}$ & $\begin{array}{l}\text { This requirement is potentially applicable to the } \\
\text { characterization and management of material } \\
\text { generated by the proposed action. Con- } \\
\text { taminated material at the site las been and will } \\
\text { continue to be evaluated to determine whether } \\
\text { the prerequisites for definition as hazardous } \\
\text { waste are met. No waste listed in this require- } \\
\text { ment has been identified for the site but such } \\
\text { testing will continue to determine whether the } \\
\text { characteristic definition is met. }\end{array}$ \\
\hline
\end{tabular}

Solid Waste Disposal Act, as amended (42 USC 6901, et seq.); Standards for Owners and Operators of Hazardous Waste Treatment, Storage, and Disposal Facilities (40 CFR 264)

with vapor generation potential, and other); or (4) lenchability, as defined by an established toxic clunacteristic leaching procedure (TCL..P). The maximum contaminant concentration in leachate for lead is $5.0 \mathrm{mg} / \mathrm{L}$.

l-lazardous wasto managenent

Requirements are established for the design construction, operation, and maintenance of facilities used to store hazardous waste, including containnent systems to control precipitation, runon, runoff, leachate, and wind dispersal in a manner that ensures protection of human health and the environment.
Potentially applicable

These requirements may be applicable to the proposed action, i.e., if material generated by the proposed action meets the prerequisites for definition as characteristic hazardous waste (no listed waste has been identified at the site). Substantive requirements for such a facility will be addressed. 


\section{TABLE A.3 (Cont'd)}

\begin{tabular}{|c|c|c|c|c|}
\hline Potential ARAR & Action & Requirments & $\begin{array}{l}\text { Preliminary } \\
\text { Determination }\end{array}$ & Remarks \\
\hline $\begin{array}{l}\text { Missouri Hazardous Substance } \\
\text { Rules (10 CSR 24); Missouri Solid } \\
\text { Waste Management Law (RSMo. } \\
260.200 \text { to 260.245) and Regulations } \\
\text { (10 CSR 80); Missouri Hazardous } \\
\text { Waste Management Law (RSMo. } \\
260.350 \text { to 260.552) and Regulations } \\
\text { (10 CSR 25) }\end{array}$ & $\begin{array}{l}\text { Hazardous } \\
\text { waste } \\
\text { management }\end{array}$ & $\begin{array}{l}\text { The owner/operator of a hazardous waste treat- } \\
\text { ment, storage, or disposal facility should comply } \\
\text { with the requirements established in these regu- } \\
\text { lations (including those for facility siting and } \\
\text { design), in addition to those of } 40 \text { CFR } 264 \text { (see } \\
\text { related discussion in this table); in the case of } \\
\text { contradictory or conflicting requirements, the } \\
\text { more stringent shall control. }\end{array}$ & $\begin{array}{l}\text { Potentially } \\
\text { applicable }\end{array}$ & $\begin{array}{l}\text { These requirements may be applicable to the } \\
\text { proposed action, i.e., if material generated by } \\
\text { the proposed action meets the prerequisites for } \\
\text { definition as characteristic hazardous waste (no } \\
\text { listed waste has been identified at the site). In } \\
\text { this case, the substantive stroage requirements } \\
\text { would be addressed. }\end{array}$ \\
\hline $\begin{array}{l}\text { Hazardous and Radioactive Mixed } \\
\text { Waste Program (DOE Order } 5400.3 \text { ) }\end{array}$ & $\begin{array}{l}\text { Mixed waste } \\
\text { management }\end{array}$ & $\begin{array}{l}\text { The hazardous waste component of hazardous } \\
\text { and radioactive mixed wastes should be } \\
\text { managed according to the requirements of the } \\
\text { Solid Waste Disposal Act, as amended, and the } \\
\text { radioactive component of radioactive mixed } \\
\text { waste should be managed according to the } \\
\text { requirements of DOE Order } 5820.2 A \text { (see related } \\
\text { discussion in this table). Waste minimization } \\
\text { measures should also be implemented. }\end{array}$ & $\begin{array}{l}\text { To be con- } \\
\text { sidered }\end{array}$ & $\begin{array}{l}\text { Although not promulgated standards, these } \\
\text { constitute requirements with which the } \\
\text { proposed action will comply if material } \\
\text { generated by the action meets the prequisites } \\
\text { for definiion as hazardous waste; in this case, } \\
\text { the substantive storage requirements of the act } \\
\text { would be addressed. }\end{array}$ \\
\hline
\end{tabular}

discussion in this table). Waste minimization measures should also be implemented. 
APPENDIX B:

ENGLISH/METRIC - METRIC/ENGLISH EQUIVALENTS 
TABLE B.1 English/Metric Equivalents

\begin{tabular}{lll}
\multicolumn{1}{c}{ Multiply } & \multicolumn{1}{c}{ By } & \multicolumn{1}{c}{ To obtain } \\
\hline acres & 0.4047 & hectares $(\mathrm{ha})$ \\
cubic feet $\left(\mathrm{ft}^{3}\right)$ & 0.02832 & cubic meters $\left(\mathrm{m}^{3}\right)$ \\
cubic yards $\left(\mathrm{yd}^{3}\right)$ & 0.7646 & cubic meters $\left(\mathrm{m}^{3}\right)$ \\
degrees Fahrenheit $\left({ }^{\circ} \mathrm{F}\right)-32$ & 0.5555 & degrees Celsius $\left({ }^{\circ} \mathrm{C}\right)$ \\
feet $(\mathrm{ft})$ & 0.3048 & meters $(\mathrm{m})$ \\
gallons (gal) & 3.785 & liters $(\mathrm{L})$ \\
gallons (gal) & 0.003785 & cubic meters $\left(\mathrm{m}^{3}\right)$ \\
inches (in.) & 2.540 & centimeters $\left(\mathrm{cm}^{3}\right)$ \\
miles (mi) & 1.609 & kilometers $(\mathrm{km})$ \\
pounds $(\mathrm{lb})$ & 0.4536 & kilograms $(\mathrm{kg})$ \\
short tons (tons) & 907.2 & kilograms $(\mathrm{kg})$ \\
short tons (tons) & 0.90718 & metric tons $(\mathrm{t})$ \\
square feet $\left(\mathrm{ft}^{2}\right)$ & 0.90718 & square meters $\left(\mathrm{m}^{2}\right)$ \\
square yards $\left(\mathrm{yd}^{2}\right)$ & 0.8361 & square meters $\left(\mathrm{m}^{2}\right)$ \\
square miles $\left(\mathrm{mi}^{2}\right)$ & 2.590 & square kilometers $\left(\mathrm{km}^{2}\right)$ \\
\hline
\end{tabular}

TABLE B.2 Metric/English Equivalents

\begin{tabular}{|c|c|c|}
\hline Multiply & By & To obtain \\
\hline centimeters $(\mathrm{cm})$ & 0.3937 & inches (in.) \\
\hline cubic meters $\left(\mathrm{m}^{3}\right)$ & 35.31 & cubic feet $\left(\mathrm{ft}^{3}\right)$ \\
\hline cubic meters $\left(\mathrm{m}^{3}\right)$ & 1.308 & cubic yards $\left(\mathrm{yd}^{3}\right)$ \\
\hline cubic meters $\left(\mathrm{m}^{3}\right)$ & 264.2 & gallons (gal) \\
\hline degrees Celsius $\left({ }^{\circ} \mathrm{C}\right)=17.78$ & 1.8 & degrees Fahrenheit $\left({ }^{\circ} \mathrm{F}\right)$ \\
\hline hectares (ha) & 2.471 & acres \\
\hline kilograms (kg) & 2.205 & pounds (lb) \\
\hline kilograms (kg) & 0.001102 & tons, short $(t)$ \\
\hline kilometers $(\mathrm{km})$ & 0.6214 & miles (mi) \\
\hline liters (L) & 0.2642 & gallons (gal) \\
\hline meters $(m)$ & 3.281 & feet $(\mathrm{ft})$ \\
\hline metric tons $(t)$ & 1.1023 & short tons (tons) \\
\hline square kilometers $\left(\mathrm{km}^{2}\right)$ & 0.3861 & square miles $\left(\mathrm{mi}^{2}\right)$ \\
\hline square meters $\left(\mathrm{m}^{2}\right)$ & 10.76 & square feet $\left(\mathrm{ft}^{2}\right)$ \\
\hline square meters $\left(\mathrm{m}^{2}\right)$ & 1.196 & square yards $\left(\mathrm{yd}^{2}\right)$ \\
\hline
\end{tabular}




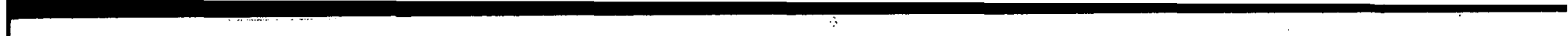

